NBER WORKING PAPER SERIES

\author{
THE ORDER OF LIBERALIZATION OF THE \\ CURRENT AND CAPITAL ACCOUNTS OF \\ THE BALANCE OF PAYMENTS
}

Sebastian Edwards

Working Paper No. 1507

\author{
NATIONAL BUREAU OF ECONOMIC RESEARCH \\ 1050 Massachusetts Avenue \\ Cambridge, MA 02138 \\ November 1984
}

\begin{abstract}
This paper was written while I was visiting the Country Policy Department of the World Bank during the summer of 1983, and presented at the World Bank Conference, Economic Liberalization: Adjustments During the Transition, Washington, D.C., October 1983. I am indebted to A. Choksi, D. Papageorgiou, L. Ahamed, M. Khan, M. Selowsky and S. van Wijnbergen for helpful discussions. I am most grateful to Daniel Gros, Deepak Lal, Ron McKinnon, Ed Tower and Jan Tumlir for very helpful comments. The research reported here is part of the NBER's research program in International Studies. Any opinions expressed are those of the author and not those of the National Bureau of Economic Research or the World Bank.
\end{abstract}


NBER Working Paper \#1507 November 1984

\section{The Order of Liberalization of the \\ Current and Capital Accounts of \\ the Balance of Payments}

\section{ABSTRACT}

The opening up of an economy to the rest of the world has generally been considered an integral part of economic reform aimed at increasing the role of markets. Until recently, however, very little discussion was devoted to the order in which the capital and current account should be liberalized in developing countries.

This paper deals with several aspects of the order of liberalization. The different arguments usually given to advocate a particular ordering are critically reviewed. Then a three-good two-factor model is used to analyze the effects of alternative ordering on production and income distribution. A two-period model of a small economy is also used to investigate the welfare effects of opening the capital account in the presence of distortions. While the discussion does not yield a theorem regarding the appropriate order of liberalization, there are strong presumptions that it is more prudent to liberalizè the current account first. 


\section{Contents}

Page

1. Introduction

2. The Order of Economic Liberalization 5

2.1 Macroeconomic Stability and Real Exchange Rate Movements 6

2.2 Welfare Effects of Alternative Orderings

2.3 Adjustment Costs and Assistance.

2.4 Summary 25

3. Prices and Resource Movements During Capital and Current Account Liberalization

3.1 The Economy Under Consideration 31

3.2 Trade. Liberalization 32

3.2.1 Long-Run Effects of Trade Liberalization 33

3.2.2 The Short-Run Effects 40

3.2.3 The Transition Period After a Trade Liberalization 47

3.3 The Liberalization of the Capital Account 51

3.3.1 Long-Run Effects 54

3.3.2 The Short-Run Effects 56

3.3.3 Transition 61

3.4 Summary 66

4. Welfare Implications of Opening the Capital ACcount in the

Presence of Trade Distortions

$\begin{array}{lll}4.1 & \text { The Model } & 70\end{array}$

4.2 Opening the Capital Account In the Absence of Trade Distortions

4.3 The Opening of the Capital Account in the Presence of Trade Distortions

5. Summary and Concluding Remarks 80

6. References $\quad 87$ 


\section{Introduction}

For many years economists have argued that developing countries should rely more heavily on the market mechanism. In particular it has been argued that Iiberalization processes, consisting of "freeing" domestic markets and opening up the economy to the rest of the world, should be implemented. A large amount of effort and resources have been devoted to the study of the relationship between the degree of market use, economic efficiency and economic growth. These studies have resulted in the accumulation of an impressive body of empirical evidence that indicates that liberalized and exportoriented economies outperform -- both in terms of growth and equitable income distribution -- repressed and closed economies. 1/ However, despite this evidence, and the widespread belief among economists of the merits of liberalizing the LDC's economies, little serious efforts to that effect have been taken by these countries. Many times liberalization attempts are frustrated at different stages, with these economies reverting to repressed inwardlooking developing strategies.

Why, then, if liberalization is so desirable don't we observe more successful liberalization attempts? There are a number of possible answers to this question. First, even if a liberalization process results in an overall (for the economy as a whole) welfare gain, there are sectors that will gain and sectors that will lose from it. If losing sectors are politically powerful they may frustrate these liberalization efforts. 2/ This problem becomes

1/ Harberger 1958; Little et al. 1970; Krueger 1978; Balassa 1971, 1982; Bhagwati 1978; Bhagwati and Srinivasan 1978; Krueger 1978, 1981, 1983. On the order of Iiberalization see Edwards (1985b).

2/ This statement, of course, assumes away the possibility of fully compensating the losers of the iiberalization effort. 
more complicated once it is recognized that short-run winners and losers may differ from long-run winners and losers [see Mayer 1970, Mussa 1974]. From a policy perspective this fact suggests that the identification of different groups affected by the liberalization process, and the possible compensation of (short-run?) losers could be important to generate a successful process. Second, to the extent that there are short-run rigidities and adjustment costs, a liberalization process may result in short-run output (and welfare) losses. Even if these losses are more than compensated in the future -- with the present value of the change in society's welfare being positive -governments may be reluctant to embark into a liberalization episode. The reason for this is that the time horizon relevant to a government may be different (i.e., shorter) than that relevant to the economy as a whole. From a policy perspective this problem indicates that the analysis of the dynamics of liberalization -- differences between short- and long-run effects -- is critical. Once this dynamic process is understood, policies aimed at reducing the short-run costs of the adjustment could be Implemented.

Third, many times liberalizations have been attempted at the same time as a major stabilization program, aimed at reducing inflation and solving a serious balance of payments crisis, is underway. ${ }^{\prime}$ As a result of this the costs of the liberalization process are confused with those of the stabllization program, with the consequent resistance against the liberalization effort.

Finally (fourth), sometines the transition between a repressed and liberalized economy is mismanaged at a macroeconomic level, generating

3' See Krueger (1978, 1981), Little (1982), Michaely (1982). 
additional costs, which can become associated with the liberalization process itself.

It is clear from this discussion that the dynamic aspects of liberalization episodes are extremely important. The transition between a repressed state and a liberalized economy should be implemented carefully, in order to avoid the abortion of the liberalization attempt itself. Among these dynamic aspects, those related to the speed and order of liberalization are particularly important. With respect to the former, the main question is how fast should an economy be liberalized? In analyzing this problem considerations related to (a) efficiency gains, (b) income distribution, (c) credibility of the liberalization reforms, and (d) feasibility of the attempt should be taken into account. $4 /$ Regarding the order of liberalization, the main question is which markets should be liberalized first. This is a complicated question that has both micro (welfare) and macro implications. At the micro level typical second-best problems are present, while at the macro level, different orders of the liberalization process will Imply different paths for the critical variables, including the real exchange rate, aggregate output and unemployment.

The present paper deals with a particular aspect of the order of economic liberalization: the order of liberalizing the current and capital account of the balance of payments. It has generally been considered that the opening of the economy to the rest of the world is an integral part of any economic reform aiming at increasing the role of markets in LDC's. Until

4/ On the speed of liberalization see Aizenman (1983), Leamer (1980), Pindyk (1982), Krueger (1983b), Mussa (1982, 1983). 
recently, however, very little discussion had been devoted to the order in which the current and capital accounts should be liberalized. $\underline{5}$ The recent experience of a group of countries from the cone of South-America -Argentina, Chile and Uruguay -- has generated new interest on the subject. These countries followed opposite orders -- Argentina and Uruguay opened the capital account first, while Chile opened the current account first -- with a common fate in the early 1980s: deep economic recession and (partial) reversal of the liberalization attempt. An important policy question that has emerged from these experiences has to do with defining liberalization policy packages (including a specific order) that would increase the possibility that the reforms will indeed be undertaken and will not be reverted.

In the present paper some of the most important issues related to the order of liberalization of the current and capital accounts of the balance of payments are surveyed. The paper is organized in the following form: In Section 2 the literature on the subject is reviewed, and some interpretations are suggested. In this section the central role of credibility in any successful policy reform is emphasized. In section 3 a positive analysis of the effects of liberalizing the capital and current accounts on production and income distribution is presented. The framework used for this discussion is a 3 goods-two factors nodel with sector specific capital in the short-run. This analysis proceeds with great detail and shows that each reform on its own will tend to have opposite effects on production and income distribution. In

\footnotetext{
5/ Of course, this question is only relevant in a world with market imperfections and/or externalities. In a world without externalities or frictions the question of the order of liberalization is trivial: all markets should be liberalized sinultaneously and instantaneously.
} 
Section 4 a two-period model of a small economy is used to investigate the welfare effects of opening the capital account (i.e., allow some foreign borrowing or lending) in the presence of trade restrictions. This discussion provides a general multi-period framework useful for analyzing the welfare consequences of partial reforms. It is shown that the welfare effects of opening the capital account in the presence of trade distortions will depend critically on whether the foreign funds obtained from abroad are used to (directly) increase present consumption or if they are used to finance capital accumulation. Finally, in Section 5 a summary and some concluding comments are presented. Also in this section some thoughts regarding future lines of research on the subject are presented.

\section{The Order of Economic Liberalization: A Review of the Literature}

The order of economic liberalization -- understood as whether the capital or the current accounts should be liberalized first -- has become an explicit topic of analysis only during the last $f e w$ years. It was basically the recent liberalization and stabilization experience of the countries of the cone of South-America (Argentina, Chile and Uruguay) that triggered a broad discussion on the subject. Since 1980 an increasing number of conferences, papers, Ph.D. theses and research projects have been devoted to the subject. $5 /$ Even though the explicit analysis of the order of liberalization of the current and capital accounts is only recent, it is possible to find some important discussions on the topic in some earlier work devoted to other

6) See, for example, McKinnon (1982), Blejer and Landau (1984), Corbo and de Melo (1981), IMF Staff Papers (June 1983), Khan and Zahler (1983), and Krumm (1983). 
aspects of economic liberalization [i.e., Mckinnon 1973, Chap. 11; Little, Scitovsky and Scott 1970, Ch. 10].

The different authors that have analyzed the order of liberalization have tended to focus on different aspects of the problem. However, in order to organize this review these arguments will be grouped into three broad categories: (a) Macroeconomic Stability and real exchange rate movements; (b) Welfare effects of alternative orderings; and (c) Costs of the adjustment process.

\subsection{Macroeconomic Stability and Real Exchange Rate Movements}

It has been suggested that the opening of the capital account of the balance of payments will result, in the short-run, in large destabilizing capital flows. If If the capital account is opened at a stage where the domestic capital market is still repressed, with interest rates fixed at artifically low levels, massive capital outflows will take place. For this reason most, if not all authors that have discussed this issue have suggested that the capital account should only be opened after the domestic capital market has been liberalized, and domestic interest rates have been raised. $8 /$ It is also generally accepted that in an inflationary environment the domestic financial market should only be liberalized after the fiscal deficit has been

I' See, for example, Mckinnon (1973, 1982), Dornbusch (1983), Corbo (1993), Arriazu (1983b), Little, Scitovsky and Scott (1970, Ch. 10, p. 365).

8/ Interestingly, in most of the literature on domestic financial markets liberalization authors have referred to "raising" interest rates rather than "freeing" them (see, for example, McKinnon's 1973 classical treatment of the subject). 
controlled. 9/ The reason for this is that, as emphasized by Mckinnon and Mathieson [1981], the existence of a large fiscal deficit, which is financed by an inflation tax, necessitates that reserve requirements are kept high and interest payments on deposits are kept low. In this way it is assured that the base on which the inflation tax is collected -- the stock of high powered money - is not eroded. 10 I

If, on the other hand, the fiscal deficit has been controlled and the donestic financial market liberalized, the presumption is that the opening of the capital account of the balance of payments will result in large inflows of foreign capital, triggered by the existence of substantial interest rates differentials [see McKinnon, 1973]. These inflows of foreign funds will then be monetized and, under a flxed exchange rate will result in inflation and a real appreciation of the domestic currency. $11 /$ If, on the other hand, the country in question chooses to adopt a floating exchange rate, the massive inflow of capital will result in an appreciation of the nominal (and real)

9/ Most of the discussion on the order of liberalization in the context of the southern cone countries has focused on the problem of liberalization with stabilization. The reason for this is, of course, that these countries attempted to liberalize and reduce extremely high inflation rates (up to $500 \%$ per year) simultaneously.

10/ See MCKinnon (1982) and :1ckinnon and Mathieson (1991) for discussions on the subject. It has been suggested that the inability to control the fiscal deficit in Argentica was one of the major causes of the failure of the recent liberalization with stabilization attempted in that country. See, for example, Rodriguez (1733), Nogues (1983), Fernandez (1983), Sjaastad (1983), Arriazu (1933) and McKinnon (1982).

11 The implicit assumption here is that as a result of the opening of the capital account an excess supply of money will be generated. 
exchange rate. 12 Not only will the opening of the capital account generate a real appreciation of the domestic currency, but since financial markets adjust fast -- indeed much faster than goods markets -- this real appreciation will be quite abrupt [see Frenkel 1982, 1983].

While the opening of the capital account will generate a real appreciation, it has been argued that a successful liberalization of the trade account will require a real devaluation of the domestic currency. This real depreciation would help the exportables sector to expand as the new structure of relative prices replaces the old protective structure. 13/ If, however, due to the opening of the capital account this devaluation is precluded, the transition in the tradeable goods sector from a protective to a freer environment will become more difficult. The appreciation generated by the opening of the capital account will tend to squeeze profitability in the tradeable goods sector at a moment when this sector (or part of it in the import substitution industries) is going through a costly readjustment. 14 / Consequently some authors have suggested that the capital and current accounts should not be open simultaneously, and that during the transition period after trade has been liberalized, capital inflows should be tightly controlled. It is

$12 /$ On the relationship between capital flows and the real exchange rate in LDCs see, for example, the discussions in Harberger (1982); Harberger and Edwards, (1982); Munoz (1982); Diaz-Alejandro (1981); Cline (1983); Calvo (1982); Corden (1982); Khan and Zahler (1983); Corbo and Edwards (1981); Corbo (1983); Arriazu (1983b); Van Wijnbergen (1982); and McKinnon (1973, 1976, 1980, 1982).

13/ See, for example, McKinnon (1973, 1982); Little, Scitovsky and Scott (1970); Balassa (1976, 1982); Michaely (1982). See, however, the discussion in Section 4 of this paper.

14/ That is an exchange rate deprotection, a la Corden (1982) will take place. 
Interesting to quote what Mckinnon wrote on the subject in 1973, since the hypothetical situation described by him closely reflects some of the problems faced by the southern cone countries during their recent (late 1970s-early 1980s) liberalization efforts:

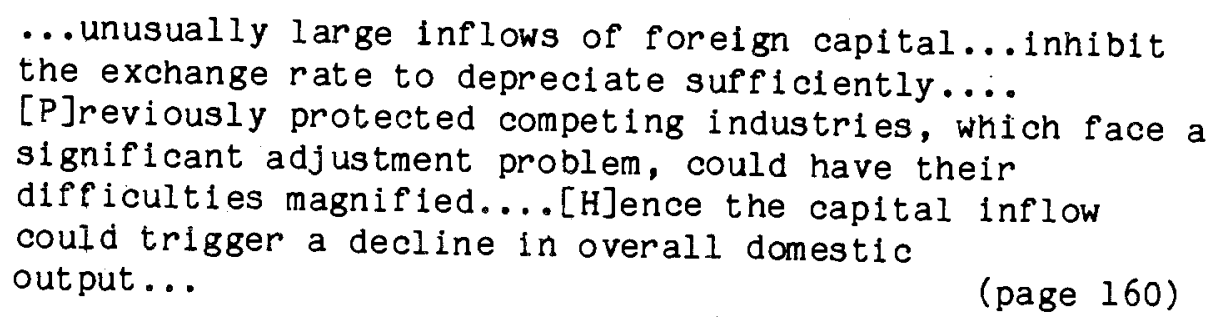

Mckinnon then goes on to recommend that an economy that liberalizes

its foreign trade should "deliberately avoid an unusual or extraordinary injection of foreign capital" [1973, p. 161, emphasis added]. More recently this kind of reasoning has also been made by Dornbusch [1983], Arriazu [1983], again by McKinnon [1982], and Harberger [1983]. The general theme is that during the transition of a trade liberalization process capital inflows should be controlled, since otherwise the real exchange rate will appreciate producing harmful effects, and even destroying the liberalizing experiment. As Dornbusch [1983, p. 176] has recently put it: "The worst thing to do is to liberalize the capital account...before the required real depreciation has been achieved".

A critical question regarding this line of argument is to what extent the freeing of the capital account will result in an "extraordinary" injection of foreign capital, in the sense of the McKinnon quote. If the opening of the capital account results in large capital inflows which are sustainable in the long-run, the resulting appreciation should be viewed as a long-run equilib- 
rium phenomenon. Under those circumstances it is not clear that the opening of the capital account should be delayed on the grounds of 1 ts effects on the real exchange rate. 15 It turns out, however, that it is not difficult to build simple models of an economy that restricts capital inflows, where an opening of the capital account will result in short-run overshooting of the level of capital inflows. Possibly one of the simplest ways of modelling this behavior is by assuming that capital inflows $(\Delta K)$ respond to the following equation:

$$
\Delta K=\min \left[\theta\left(D^{*}-D_{-1}\right), \overline{\Delta K}\right]
$$

where $D^{*}$ is the desired or sustainable level of foreign debt, which will depend on the level of "the" world interest rate, real income, real wealth and the perceived profitablitity of investments at home, among other things. $D_{-1}$ is the actual stock of debt in the previous period, $\theta$ is a partial adjustment coefficlent, and $\overline{\Delta K}$ is the maximum (possibly zero) amount of (net) capital inflow allowed by the economic authority in every period. $16 /$

15/ See the discussion in Stockman (1982) on the merits of opening the capital account as soon as possible.

16/ The term $\theta\left[D^{*}-D_{-1}\right]$ responds to the idea, advanced by Harberger (1982) for example, that there is a long-run equilibrium ratio of foreign debt

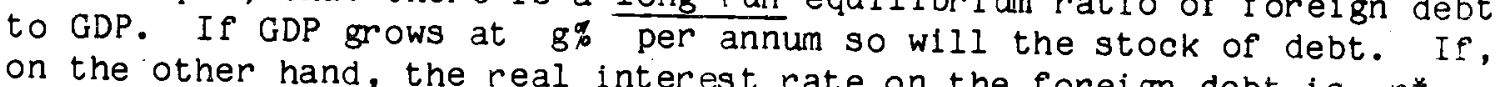
net annual capital inflows will grow ate on the foreign debt is $r^{*}$, a problem with this formulation is that 1 t onl of $\left(g-r^{*}\right)$. Notice that che whe foreign debt is accumulated, and does not explicitly incorporate the existence of an intertemporal budget constraint. On the different phases of the accounts of the balance of payments see Fischer and Frenkel
$(1972)$. 
Clearly, if $\overline{\Delta K}<\theta\left(D^{*}-D_{-1}\right)$ the gap between desired and actual debt will increase through time. Once the restrictions on capital inflows are lifted, actual inflows will become equal to $\theta\left(D^{*}-D_{-1}\right)$. That means that immediately following the opening of the capital account capital flows will jump to a fraction $\theta$ of the accumulated gap between the desired and actual debt. As this gap is closed, the level of capital inflows will slowly be reduced until they reach a new equilibrium level. For the case of a simple economy the behavior through time of capital flows that emerges from this formulation can be represented in Figure 2.1. Alternatively, it is possible to assume that once the capital account is liberalized the percelved profitability of domestic investment will dramatically increase [McKinnon, 1973]. Th1s will result in a (significantly) higher $D^{*}$-- sustainable level of foreign debt -- and in a jump in the level of capital inflows, as shown in Figure 2.1 .

This sudden increase (i.e., overshooting) of capital inflows will produce a large current account deficit -- as was the case of Chile during 1980-1981. 17/ As has been pointed out by McKinnon (1976), Corden (1982) and Harberger (1982, 1983)) among others, as long as a fraction of these flows are spent on non-tradeable goods, the absorption of these capital inflows will require an increase in the relative price of these goods and a real apprecia tion of domestic currency. $18 /$ Once the gap between desired and actual debt begins to close, the relative price of non-tradeables will slowly tend to

17 I See Harberger (1982), Corbo (1933), Edwards (1984). See also Nogues (1983) and Rodriguez (1983) for a discussion of the Argentinian case.

18/ Harberger (1982) actually calculated that the increase in the level of capital inflows in Chile is capable of "explaining" a real appreciation of the peso of up to 25 percent. 
decline towards its new long-run equilibrium. At this point of the adjustment process another problem may emerge if the country has fixed its exchange rate: If for some reason -- the existence of minimum wages, or of backward indexation, for example -- the nominal price of non-tradeables is inflexible downward, the decline of this relative price will not occur, and unemployment will result.

It is interesting to notice that the dynamic effect of a capital account liberalization on the relative price of nontradeable goods resembles that of the Dutch-Disease, in that in order to adjust to a large increase in absorption a real appreciation of the domestic currency will have to take place. 19/ Also, it should be pointed out that there are other reasons besides the "jump" in the level of capital flows discussed above, why the opening of the capital account could result in a short-run appreciation of the domestic currency that will exceed the long-run appreciation. One of such cases is related to the difference between short- and long-run elasticities of supply of the nontradeables goods sector.

The conflicting movements of the real exchange rate as a result of opening the capital or current accounts (i.e., real appreciation and depreciation respectively) captures the fact that these policies will exercise pressures for resources to move in opposite directions. The opening of the capital account will generate (at least in the short-run) an expansion of the non-tradeable goods sector and a contraction of the importables and $19 /$ On Dutch-Disease see, for example, Corden (1981, 1982), Corden and Neary
(1982), Harberger (1982), Edwardis and Aoki (1983), Van Winjbergen $(1984 a, b)$. 
exportables sectors. 20 The opening of the current account, on the other hand, will result in an expansion of the exportables sector, a contraction of the production of importables, with the nontradeables sector either expanding or contracting [see the discussion in Section 3 below]. To the extent that there could be advisable to implement policies that would avoid unnecessary resource switches (i.e., resource movements that will be reversed after a short period of time). 21 / In particular a synchronization of the effects of opening the capital and current accounts, in the sense suggested by Frenkel [1982, 1983] might be called for. Frenkel has proposed that given the differential speeds at which the goods and capital markets adjust, this synchronization could be achieved by opening the current account first, and only after some time opening the capital account. In Section 3 below, a specific analysis of the effects of both types of liberlization, that spells out the difference between short- and long-run effects on resource movements is presented.

An alternative view has been recently presented by Deepak Lal

[1982]. According to Lal, since exchange rate behavior is critical during the transition period from a protected towards a liberalized trade account, it is better not to let the government manipulate the nominal exchange rate during this transition. There have been plenty of cases, he argues, where exchange

20/ This indeed has been the case in countries that have opened the capital account. In Chile, for example, after the capital account was opened in $1979 / 80$, an important fraction of the massive capital inflows was used to finance the expansion of the construction sector. This was also the case of Argentina and Uruguay (see Nogues 1983; Hanson and de Melo 1983).

21/ A critical question at this stage is why wouldn't the private sector take into account these considerations when making their decisions about production and resource movements. 
Flgure 2.1

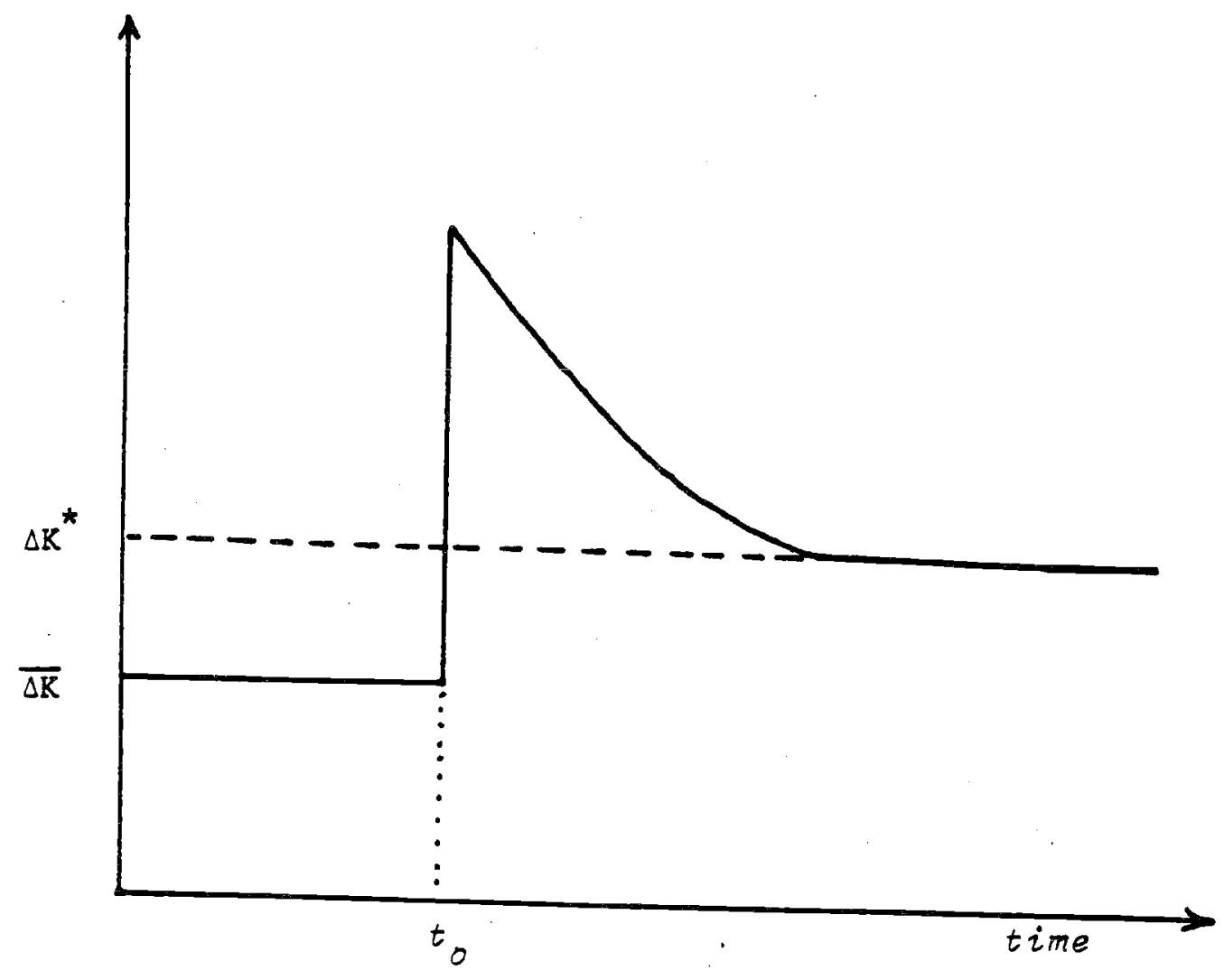


rate management has been inappropriate and has resulted in the trade reform being finally aborted (i.e., the recent experience of Argentina). 22 For this reason Lal has proposed that a floating exchange rate system with full currency convertibility, should be implemented before the trade reform takes place. This, of course, means that the capital account should be liberalized before the trade account. A problem with this proposition however is that Lal does not spell out how to handle the real appreciation problem resulting from the opening of the capital account -- even though admittedly its effects will be less severe if the trade side has not been reformed yet, $23 /$ nor does he specify how much in advance the capital account should be opened. Also, in his discussion on the subject Lal does not refer to the institutional setting that would be required for a floating exchange rates system to succeed in a developing country. $24 /$

\subsection{Welfare Effects of Alternative Orderings}

A second line of argument used in discussions related to the ordering of economic liberalization refers to traditional welfare analysis. It has

Other authors that discuss how to handle the exchange rate during the transition period after a trade reform include McKinnon (1973), Kapur (1983), Michaely (1982), Balassa (1982). One possible way to deal with the exchange rate problem during the transition is to adopt a dual system, with a fixed (or managed) rate for trade transactions, and a floating rate for financial transactions. The problem with this kind of system, however, is that it becomes very cumbersome and difficult to manage. On dual exchange rate systems see, for example, Meade (1951, p. 302); Flood (1978); Lainy (1975, Fleming (1974) and Dornbusch (1976).

23 ' On this, see however, Branson (1983).

24 Some authors have argued that due to the lack of some basic institutional requirements (freely) floating exchange rates systems are not feasible in developing countries. See, for example McKinnon (1979a,b). 
been argued that if the current and capital accounts are not liberalized simultaneously there might be welfare implications of reducing one distortion while other distortions are kept in place. 25/ This kind of argument has been made by Frenkel [1982, 1983], Krueger [1983] and McKinnon [1973]. These authors have generally concluded that welfare considerations indicate that the current account should be liberalized first. The main reason for this is that the (negative) indirect welfare effect of opening the capital account in the presence of trade distortions will exceed the indirect effects arising from the opposite ordering. McKinnon [1973, p. 157], for example stated that "the liberalization [of] capital inflow[s]...increase[s] the basic distortion in the economy". Frenkel [1983], has expressed that

when the trade account is opened first the cost of remaining distortion (i.e., the closed capital account)... is likely to be relatively small. On the other hand, when the capital account is opened up first the cost of the remaining distortion (i.e., the close trade account)... is likely to be very large. Thus a comparison of the costs of distortions... supports the proposition that the trade account should be opened first.

Kruger [1983] has stated that

Since exchanges of assets are exchanges of capitalized values of income streams, income streams generated by distorted prices are probably the inappropriate ones at which to trade. It would then follow that capital account liberalization should not be undertaken unless both current account and domestic financial transaction are already liberalized.

In some sense this type of reasoning, which focuses on the welfare effects of opening the capital account in the presence of trade distortions,

$25 /$ As mentioned in the introduction, in a world with no distortions the optimal (i.e., welfare maxinizing) strategy is to liberalize both accounts simultaneously and instantaneously. 
can be related to the Immiserizing capital accumulation argument originally advanced by Harry Johnson [1967]. 26/ This argument points out that if there are tariffs and the importable goods is capital intensive, capital accumulation may be welfare reducing. The reason for this is that when capital is accumulated, production of the capital intensive (i.e., the importable) sector will increase, [Rybczynski 1955], and the effect of the pre-existing distortion will be reinforced. This effect can be strong enough, so that the accumulation of capital will result in a reduction of welfare. $27 /$ An obvious question at this point is why would the recipients of capital inflows use them to accumulate capital (i.e., to invest) if welfare might be reduced? The answer is that while from a private perspective the accumulation of capital may be beneficial, since under our assumptions regarding capital intensity, the domestic rental rate of capital will exceed the world rental rate, $28 /$ from a social perspective, it will be less desirable -- and could even be immiserizing. This suggests, then, that if once the capital account is opened investment decisions are made using shadow prices, welfare will never decrease [see Edwards and Van Nijnbergen 1983].

26/ Of course, immiserization represents an extreme case. However, the analytics of this case can be applied to more plausible results, where the increase in welfare resulting from capital accumulation is lower in the presence of trade distortion. See also Bertrand and Flatters (1971) for extensions on the welfare effects of the accumulation of capital.

27/ The condition for this welfare reduction to take place is that the Rybczynski line is flatter than the world's relative price line. See Johnson (1967).

28/ This, of course, according to so:per-Samuelson's theorem. 
The analysis of the welfare effects of foreign investment in the presence of tariffs -- as developed by Bhagwati and Srinivasan [1982], and Brecher and Diaz-Alejandro [1977], among others -- can also be useful for the present discussion regarding the order of liberalization. Brecher and DiazAlejandro, for example, have shown that in the presence of tariffs if the importable goods is capital intensive a small amount of foreign investment will always be welfare reducing if foreign capital is paid its marginal product. This will happen even if the conditions required for the Johnson [1967] immiserization discussed above, do not hold. If, however, the return to foreign capital is taxed, foreign investment may be welfare improving. They argue that if the amount of this tax is equal to the difference between capital's marginal productivity valued at domestic prices, and capital's marginal productivity valued at world prices, welfare will remain unaffected. Again, the main reason for this result lies on the fact that under the assumption that the importable goods is capital intensive foreign investment -- or for that matter any form of capital accumulation -- will result in an increase in the production of the sector that already produces too much from a social perspective.

In general, the welfare effects of additional investment resulting from the liberalization of the capital account can be analyzed within the context of the emerging literature on factor trade. $29 /$ If before the liberalization process the (private) domestic rate of return to capital exceeds the world rate of return, once foreign borrowing is allowed some of (1983), Brecher and Findlay (1983), Brecher (1983) and Srinivasan (1983). 
these funds will be used for the importation of machines. Analytically this is equivalent to allowing trade in machines (today), and thus can be analyzed within the factor trade framework.

The above discussion -- and, to some extent, the argument of Mckinnon [1973], Frenkel [1982, 1983] and Krueger [1983] presented above -- focus exclusively on the case where, as a result of the liberalization of the capital account, the additional borrowing is used to increase investment. This, of course, needs not be the case. A fraction (possibly zero) of the new borrowing could be used to increase present consumption. Indeed that will happen as long as prior to the liberalization the domestic rate of time preferences exceeded the world rate of interest. It is easy to show that, under these circumstances, if all of the (new) foreign borrowing is used for additional present consumption (with the world rate of interest below the domestic rate of time preferences) welfare cannot deteriorate even if there are tariffs.

We now briefly turn to discuss the welfare effect of liberalizing trade in the presence of a closed capital account. The question here is if there are circumstances under which this particular order of liberalization will result in some indirect negative welfare effects. $30 /$ In principle, at a theoretical level, it is conceivable that some models might yield this kind of result. Specifically, if the restricitons in the capital account take the form of a tax on foreign borrowing that introduces a wedge between the world and domestic rates of interest, and the liberalization of the current account

30/ A different, and more relevant question of course, is whether the total -direct plus indirect effects -- can be negative. 
results in a reduction (i.e., leftward shift) of the demand for foreign borrowing, an indirect negative welfare effect could result.

In practice, however, this case is quite implausible. First, it is unlikely that the reduction of tariffs will generate a reduction of the demand for foreign borrowing. The reason for this is that once tariffs are reduced the demand for importables will increase, with part of the increase in consumption of this type of goods being financed by additional foreign borrowing. $31 /$ Second, in a large number of cases the distortions associated with capital account take the form of quantitative restrictions, where a given maximum amount of foreign borrowing is allowed. In this case then, there is no indirect welfare cost (i.e., welfare rectangle), in the borrowing market associated with the reduction of trade distortions. In general, these considerations constitute a part of the presumption that trade liberalization is welfare improving even if distortions in some other markets are maintained [Krueger 1983; Michaely 1982; Corbo and de Melo 1981].

\subsection{Adjustment Costs and Assistance}

Some authors have postulated that in order to increase the probability of success ( $1 . e .$, non-reversal) of a trade reform, the adjustment costs (unemployment and others) related to the tariffs reduction should be

31/ There is an important problem, however, related to the speed of tariff reductions. It is conceivable that if a slow tariff reform schedule is announced today, borrowing will decrease, since the public will postpone consumption towards the future, when tariffs will be lower. 
minimized [see for example Michaely, 1982], 32/ It has then been argued that one way of reducing these adjustment costs is through the importation of foreign capital, which would be used to finance a smoother adjustment of the import competing industries. According to this view then, the capital account should be opened first, or simultaneously with the trade account. This would increase the availability of "cheap" funds that could then be used to ease the adjustment process. Paul Clark [1982], for example, argues that the successful liberalization of the Egyptian economy in the 1970s was due, to a large extent, to the adjustment assistance provided by foreign sources. Anne Krueger [1983a] on the other hand, while not agreeing with the order "capital account first and trade-account second", has also recognized the possible important role of foreign funds to help achieve a smoother transition. As she puts it: $\underline{33}$

[0]ne of the important contributions international lending can make to a country when its leaders are genuinely committed to full liberalization, [is to]... permit higher levels of imports than would otherwise be feasible.... Not only does this reduce the economic and political strains associated with liberalization, it also reduces uncertainty of business as to the likelihood that. liberalization will persist. [1983a, p. 11].

The arguments for using foreign funds to smooth the adjustment process during a trade liberalization episode are, to some extent, equivalent

32/ Usually the idea of minimizing adjustment costs is translated into two forms of policy recommentations: (1) liberalization of trade should be done slowly [see Michaely 1982; Little, Scitovsky, Scott, 1970); and (b) adjustment assistance -- usually in the form of foreign funds -should be provided.

33/ See also, for example, Little, Scitorsky and Scott (1970, Ch. 10); Michaely (1982, p. 17). 
to the arguments in favor of providing adjustment assistance to industries that are negatively affected by (exogenous) changes in the terms of trade. A recent NBER study edited by Jagdish Bhagwati [1982] contains a number of interesting papers on the subject. $34 /$ As Bhagwati himself puts it in the introduction to this volume, the analysis of the adjustment assistance issue requires knowing the path the economy will take following the change of relative prices ( $1 . e .$, changes in terms of trade and/or tariff reductions). According to the simple textbook case, following a change in relative prices, resources will immediately move out of the sector whose relative price has declined and into the expanding sector. In more complex models however, there will be adjustment costs and resource reallocation will only take place slowly, and will possibly result in a short-run loss of output. 35/ However, it is very important to clearly specify the nature of these adjustment costs before making inferences regarding the desirability of intervention. If these costs are related to the activity of moving resources between sectors, as in Mussa's [1978] model, and there are no externalities, there is no welfarerelated reason to provide adjustment assistance. $36 /$ If, on the other hand, adjustment costs arise from market imperfections -- like the existence of minimum wages for example -- there is some room for intervention. The first best policy, of course, is to try to eliminate the source of these market

34/ See, for example, Bruno (1982), ileary (1982), and Mussa (1982).

35/ The most popular models with adjustnent costs are of the Ricardo-Viner type. See for example Jones (1971), Mayer (1974), Mussa (1974, 1978, 1982), Neary (1978, 1982), and Jixit and Norman (1980).

36/ However, adjustment assistance $n ! g$ ht be called for other reasons, like income distribution considerations. See Leamer (1981). 
imperfections. If, for whatever reason, this first best policy is not avallable, second best solutions should be sought.

McKinnon [1973, 1982], however, has strongly opposed the idea of using foreign capital flows to assist the trade reform transition period. In fact, in his 1973 book he characterized aborted 1 iberalization episodes as "partial liberalization with foreign capital" [1973, p. 155]. This view, which is consistent with his position of tightly controlling capital inflows throughout the trade liberalization, is based on the idea that short-term capital movements provide incorrect signals to the private sector:

[T]rade liberalization should proceed without relying on unusual short-term inflows of private capital... Such capital inflows are simply not sustainable in the long-run; and during the 1 iberalization process itself they throw out incorrect market signals. [1982, p. 163]

There are two problems with this view. First, it is not clear what is meant by "unusual" inflows of capital. Second, there is no theoretical a priori reason to believe that these "unusual" capital inflows will provide the wrong signals. In order for this argument to make sense it is necessary to explicitly specify why the private sector will not realize (as the government presumably does in McKinnon's model) that these inflows are temporary and "unusual". If, on the other hand, the private sector does realize the temporary nature of the inflows, they will not throw incorrect signals and there is no reason, at least on these gounds, to restrict capital movements.

A critical question regarding this problem is related to the credibility of the trade reform. If the public believes that there is some probability that the reform will be reversed in the future, foreign funds, obtalned through the opening of the capital account, may be used by the owners 
of capital in the import substitution industries to maintain their firms functioning at a (temporary) loss. Alternatively, these funds could be used to finance lobbying activities aimed at convincing the government officials of the desirability of reversing the trade reform. 37 '

Also, if agents believe that the trade reform will be reversed, they will tend to borrow heavily today, in order to finance a higher present consumption. This, of course, is a rational strategy if it is expected that (Importable) goods in the future will be more expensive, due to the perceived hike of tariffs. This optimal behavior from a private perspective, however, may result in excessive (i.e., non-optimal) borrowing from the social point of view.

The above discussion suggests that depending on the degree of credibilty a larger availability of forelgn funds may elther help the adjustment process -- by making it politically more pallatable as Krueger suggests -- or may frustrate the whole experience. However, the degree of credibility -which is oritical for the analysis of the order of liberalization -- should not be viewed as an exogenous variable. On the contrary, the strategy followed during the liberalization process will affect the degree of credibility. If the economic reforms are pursued in a way such that credibility is low, agents will not make the required adjustments and the likelihood of failure of the economic reform will be high. In that sense, a fundamental and critical aspect of establishing credibility is related to the internal consis-

37' As Carlos Rodriguez (1983) has documented it, this was the recent case of Argentina. 
tency of the policies being pursued. $38 /$ In that respect, for example, the inconsistency of the Argentinian fiscal policy -- which maintained a very large fiscal deficit -- and the pre-announced exchange rate policy severely undermined the degree of credibility of the whole reform package. $39 /$

\subsection{Summary}

In this section the literature on the order of economic liberalization has been reviewed and discussed. The discussion has basically abstracted from the relationship between liberalization and stabilization (see however the brief discussion in Section 5 of this paper) and has focused on different arguments used to suggest a speciflc ordering for liberalizing the capital and the current accounts of the balance of payments. It is important to emphasize that a large part of this literature has asked the following question: given that the liberalization of the trade account (1.e., the dismantlement of $Q R^{\prime}$ 's and reduction of tariffs) is a policy objective, should the capital account be opened simultaneously, or only after tariffs have been reduced? In that sense, then, the existing literature has focused on a narrower question than the one addressed here. In this section the arguments that have appeared in the (brief) literature on the subject were organized into three broad categories:

(a) macroeconomic stability and real exchange rate movements; (b) welfare effects of alternative orderings and (c) adjustment costs and assistance.

$38 /$ On problems of credibility in the context of anti-inflationary policy see Schelling (1982), Taylor (1982) and Fellner (1982).

39/ See Sjaastad (1983) for an illustration of the degree of inconsistency of these policies using an inflation tax view. 
An interesting policy question related to the order of liberalization advocated by MoKinnon, Frenkel and others -- "current account first" -- stems from the recent Chilean experience. Chile followed almost exactly the McKinnon-Frenkel order, liberalizing the trade account first and only after tariffs had reached their final goal of $10 \%$, partially opening the capital account. $40 /$ However, the Chilean economy recently entered into the worst recession in its history with real output declining by $15 \%$ in 1982 . While a complete analysis of the Chilean experience is well beyond the scope of the present paper, $41 /$ it is possible to point out some of the major causes of the the Chilean crisis. First, the adoption of a fixed exchange rate to the dollar (in June 1979), at the same time as real wages were fully indexed created serious policy inconsistencies. The pegging of the peso, in the presence of massive capital inflows in 1980 and 1981 resulted in a real appreciation of the Chilean peso of almost $30 \%$, which was translated into an important loss of competitiveness of the tradeables goods sector. This situation was aggravated by the presence of extremely high real rates of interest -- partially generated·by generalized expectations of a large devaluation --, the world recession, and the deciine in Chile's terms of trade. The failure to take corrective policy measures in time aggravated the situation, generating speculation against the peso, with the consequent loss of international reserves.

40/ McKinnon (1982, p. 159) states that "The correct order of liberalization... approximates the successful Chilean experience after 1975. Chile is to be treated as a norm or standard of reference."

41/ On the recent Chilean experience see Harberger (1982), Corbo (1983), Edwards (1984, 1985a) and Sjaastad (1983). 
The Chilean experience indicates the macroeconomic management following a liberalization attempt is much more difficult than what it has been thought. Also, this case confirms the central role of expectations and credibility in any major economic reform. If credibility is low, and there are expectations of policy reversal, it will be very difficult for the reform to succeed. Since, as it was argued above, expectations and credibility are largely endogenous, one of the considerations that should be taken into account when formulating the reform policy is to set the speed and ordering of the liberalization in a way such that these expectations of reversal will be low. 42 '

An important problem related to the opening of the capital account, which has not received the attention it deserves has to do with the level of foreign indebtedness resulting from the opening process. $43 f^{\circ}$ The main question here is to what extent can a liberalization of the capital account result in a foreign debt crisis because the private sector over-borrows? In principle, it could be argued that this is unlikely, since the private sector, which now faces the "correct" signals, will take loans only if the marginal return obtained from those funds exceeds the cost of the loans. Theoretically, in the simplest class of models, the free interaction between the

$42 /$ of course, this is more easily said than done. The role of policy credibility is clearly one of the more important topics of macroeconomic research at the moment. Some early and promising contributions on the subject include Taylor (1982), Schelling (1982) and Fellner (1982).

43/ McKinnon (1973), however, briefly mentions this problem in his taxonomy of the successful and unsuccessful 1 : beralization attempts. 
private domestic sector and the foreign banks will result in an optimal borrowing/lending strategy. From a practical point of view and in more sophisticated models, however, there are a number of reasons to believe that this will not be the case. First, as the recent experience of some LatinAmerican countries has shown, the distinction between private and public foreign debt is highly artificial. Once a country's private sector runs into debt problems, the government takes over (or is forced to take over) this private debt. $44 /$ This means that to the extent that the private sector knows that it will be balled out by the government, the possibility of moral hazard type of behavior becomes highly likely. Under these circumstances, there will be an important difference between socially and privately optimal borrowing strategies, with a tendency on behalf of the private sector to over-borrow. Second, contrary to the textbook case, even small countries cannot borrow infinite amounts at "the" given world rate of interest. Quite the contrary, even small countries face (up to a certain point) upward sloping supplies of foreign funds, where the interest rate charged is an increasing function of the amount borrowed. 45 ' This fact also suggests that the private sector will tend to over-borrow once the capital account is opened. Specifically, there is an argument for imposing an optimal tax on borrowing at a rate of $1 / \varepsilon$, where $\varepsilon$ is the elasticity of supply of foreign funds. And third, if the private sector expects that the trade reform will be reversed in the

44/ See, for example, Diaz-Alejandro (1983).

$45 /$ See MCDonald (1982) for an exhaustive review of issues related to country risk. See also Edwards (1984) and Harberger (1976, 1980). 
future (i.e., that tariffs will be raised), they will perceive a very low consumption interest rate (measured as the rate at which they can exchange traded goods between today and tomorrow) today, and will thus tend to increase its foreign borrowing. $46 /$ While this is a perfectly optimal strategy from the private point of view it may not be so from a social perspective.

\section{Prices and Resource Movements During Capital and Current Account} Liberalization

The purpose of this section is to set up an analytical framework for analyzing the process of economic liberalization in a small economy. The discussion will focus on two different aspects of economic liberalization: (a) the liberalization of foreign trade, and (b) the liberalization of capital flows (i.e., allowing foreign borrowing), and will emphasize price and resource movements during the liberalization episode. The analysis presented here is largely positive and develops a model of a simplified economy, with three goods and two factors. The discussion traces in detail how both reforms will affect prices, resource movements and production in the short and longrun. The analysis is largely based on the extension of the viner-Ricardo model for the case of three goods as presented by Corden and Neary (1982). The model used assumes that there is no capital accumulation. For this reason, the analysis of the effects of opening the capital account is somewhat simplified, since it assumes that all funds obtained from abroad are used to increase present consumption. However, the framework presented here can be

46/ See Dornbusch (1983b) for a discussion on the subject. See also Martin and Selowsky (1984). 
also used to deal with the more general case where capital accumulation is also allowed. 47 !

The main objective of the analysis presented here is to provide a clear picture of the real consequences of the process of economic liberalization, including changes in production and in income distribution. At the risk of being repetitive, the analysis proceeds slowly, trying to make clear every important step in the chain of events that follows a liberalization episode. The model developed in this section shows that as a result of each of these reforms on their own resources and production will tend to move in opposite directions. Also the effects on income distribution of both reforms will be the opposite. While a trade reform (i.e. the removal of tariffs) will result in resources moving into the exportables sector; the opening of the capital account will result in resources moving out of that sector. To the extent that resource movements involve some costs, this fact suggests that from a policy perspective some efforts should be made to coordinate the real effects of the two reforms. A general principle that should be considered when determing the order of these two reforms in that the (unnecessary) reversal of resource movements should be avoided. $48 /$ Then, the opening of the two account should be synchronized in a way such that resources do not move in and out of a sector in a short period of time, since the economy will incur an unnecessary cost.

47/ In Section 4, however, a more general model that allows for foreign funds to be used both to increase present consumption and to accumulate capital is presented.

48/ It is important to note that in the real world this should be only one of the principles used for determining the correct ordering. Others - not mentioned in this section due to the nature of the model-- refer to issues related to credibility and continuity of the reform. 


\subsection{The Economy Under Consideration}

Assume the case of a small country that produces three goods:

exportables $(X)$, importables $(M)$ and non-tradeables (N). Production is carried out using capital and labor. Production functions have the conventional properties and it is assumed that in the short-run capital is sectorspecific, with labor being perfectly mobile between the three sectors. $49 /$ Imports are initially subject to a tariff, and external borrowing is not allowed. With respect to the labor market, it will be assumed that it is free of distortions. However, the consequences of assuming the existence of an economy wide minimum wage, which is binding in the short-run, will also be investigated. The domestic capital market is free of distortions, with the rental rates of capital being equalized in the long-run, across sectors. Regarding factor intensity, it will be assumed that importables have the highest capital/labor ratio. With respect to exportables and non-tradeables, alternative assumptions regarding factor intensities will be briefly discussed in sub-section 3.2 .1 .

A critical assumption made in this section is that there is no capital accumulation and, consequentiy, once international borrowing is allowed, the proceeds of foreign loans are fully used to increase present consumption. 50/ In that sense, then, it is assumed that at the initial point the rate of time preference exceeds "the" world rate of interest. The analysis presented

49/ On sector-specific models see, for example, Jones 1971; Mayer 1974; Mussa $1974,1978,1982$; Neary $1978 \mathrm{a}, \mathrm{b}, 1982$.

$50 /$ In that sense, then, this analysis from the possibility of negative welfare effects of allowing foreign investment in the presence of tariffs. On this, however, see section 4 of this paper. 
here also assumes that there is no initial inflation, and that tariff proceeds are returned to consumers in a nondistorting lump-sum fashion. These two assumptions represent a simplification of the real world characteristics of countries that have embarked in liberalization attempts. As has been pointed out by Krueger (1981), (1983) and Little (1982), among others, most liberalization attempts by developing countries have started from crises situations with high inflation. However, by ignoring inflation in the present section, it is possible to focus on issues related to liberalization, abstracting from those of stabilization. On the relationship between stabllization and liberalization, however, see Krueger (1981). See also Section 6 of this paper.

\subsection{Trade Liberalization}

In this section the effects of reducing (eliminating) tariffs in a three-goods small economy are investigated. It is assumed, for analytical convenience, that initially there are no quantitative restrictions (or that they have been already replaced by tariffs), and that the exchange $r$ ate is fixed and equal to one. It is also assumed that capital is sector specific in the short-run, while it can freely move between sectors in the long-run. The discussion will first deal with long-run effects, then, the short-run effects and the transition towards the long-run will be discussed. The analysis will concentrate on the behavior of good prices, factors rewards (i.e., income distribution) and production. It is assumed that while all prices are flexible in the long-run, some of them (i.e., wages) may be rigid in the short-run. 


\subsubsection{Long-Run Effects of Trade Liberalization}

In this class of models of a small economy with three goods (importables, exportables and non-tradeables), two factors (capital and labor), and the usual competition assumptions, long-run domestic prices are fully determined (under non-specialization) by world prices, technology and tariffs. Equilibrium can be described in the following way: world prices of exportables and importables (plus the tariff) determine the rewards to both factors of production; these rewards, on their turn and under the assumption of competition, determine the price of non-tradeables. Demand considerations for nontradeables determine total output of non-tradeables and total factors used in their production. This leaves a certain amount of factors that is used in the production of exportables and importables in a traditional Hecksher-Ohlin $(\mathrm{H}-\mathrm{O})$ fashion.

In the rest of the analysis the price of exportables will be taken to be the numeraire (i.e.., $\left.P_{x}=1\right)$. Consider now the effect of a reduction (elimination) of the level of the import tariff on the relative prices of final goods and on factors rewards. This effect will basically depend on the assumptions made regarding factor intensities. Two cases will be considered here: Case 1 assumes $(K / L)_{X}<(K / L)_{N}<(K / L)_{M}$; while Case 2 assumes $(K / L)_{N}$ $<(K / L)_{X}<(K / L)_{M}$.

Consider first Case 1, where imports are assumed to have the highest capital labor ratio with exports having the lowest. The effect of a reduction of the tariff on factor rewards and the relative price of non-tradeables ${ }^{P_{N}}$ can be analyzed using Figure 3.1, which is the dual to the well-known LernerPearce diagram. The intial equilibrium is given by the intersection of the 
three isocosts $M M, X X$ and $N N$. These curves present the combinations of wages and rental rates of capital that result in a constant cost of producing these goods at the existing technology [see Mussa, 1979]. The slopes of these curves are equal to the capital labor ratio, and as may be seen in Figure 3.1 , correspond to the assumptions of Case l. Initially equilibrium is obtained at A with a wage rate (relative to exports) equal to $w_{0}$ and a rental rate equal to $r_{0}$.

The reduction of the imports tariff will result in a leftward shift of the $M$ curve towards $M^{\prime} M^{\prime}$. The reason for this is that now, in order to manitain equilibrium between domestic costs and the world price of importables, plus the tariff, lower combinations of wages and rental $r$ ates will be required. New long-run equilibrium will be obtained at $B$ where the new $M^{\prime} M^{\prime}$ curve intersects the XX curve. As the Stolper-Samuelson theorem indicates, the reduction of the import tariff in an economy where exportables are labor intensive, will result in higher wages and lower rental rates (i.e.. $w_{1}>w_{0}$, and $\left.r_{1}<r_{0}\right)$.

The new equilibrium point $B$ is below the NN isocost, indicating that as a consequence of the tariff reduction the price of non-tradeables in terms of exportables will have to fall. This conclusion, of course, will not hold under Case 2, where non-tradeables are more labor intensive than exportables. In that case the intersection of the $X X$ and $M^{\prime} M^{\prime}$ curves will be above the NN curve, and in order to restore equilibrium in the non- 
Figure 3.1

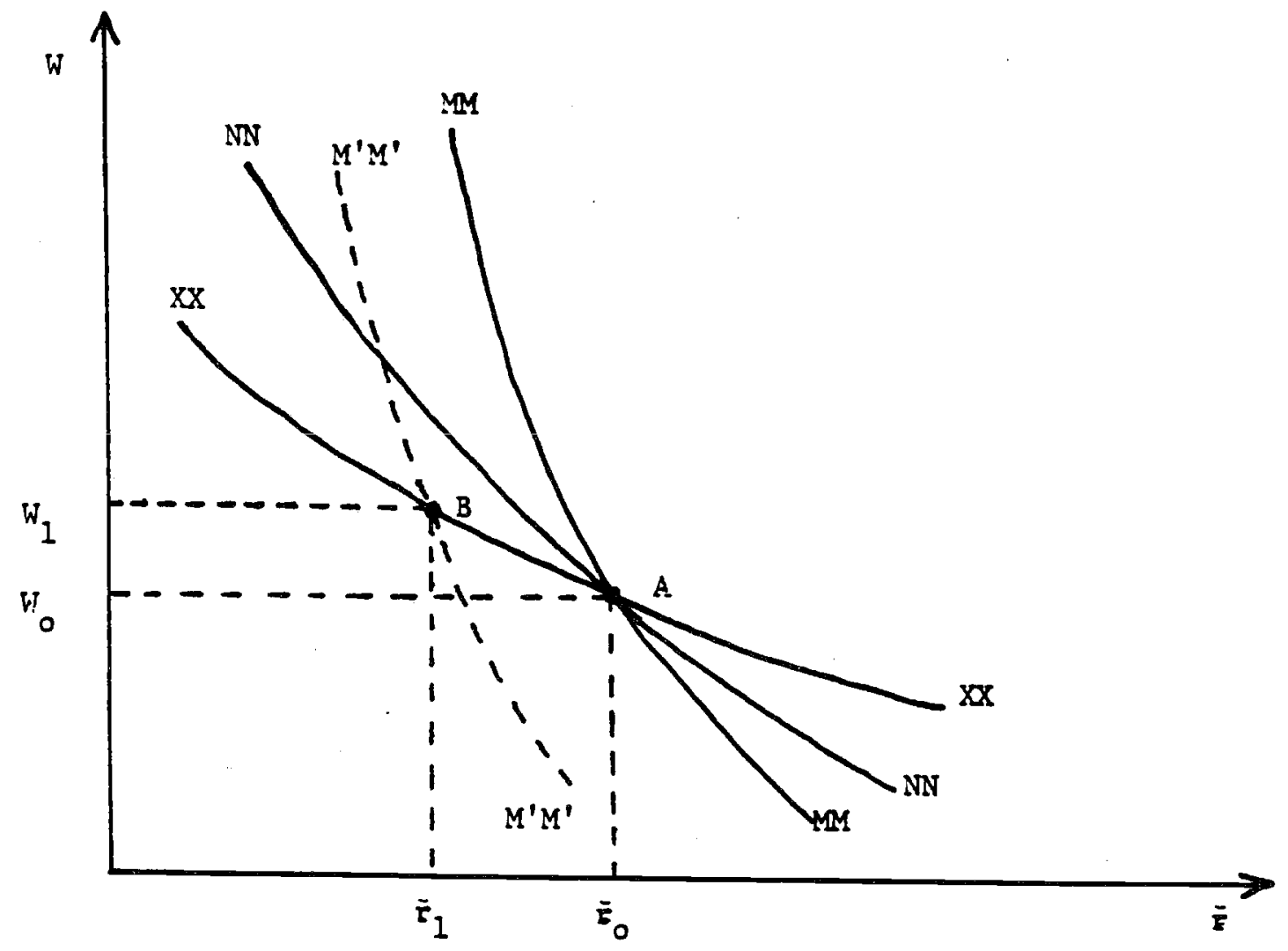


tradeables sector their relative price will have to increase. 51 In order to simplify the discussion, through the rest of this paper we will focus on Case 1, $\left[(K / L)_{x}<(K / L)_{y}<(K / L)_{M}\right]$.

While the long-run (relative) price of non-tradeables is completely determined by technological considerations, the amount produced of this type of goods will also depend on the demand side. In particular, production of $\mathrm{N}$ will be such that, at the prevailing prices, the non-tradeables market clears. The production side of the model can be analyzed using a three goods Edgeworth-Bowley box as developed by Melvin (1968). Figure 3.2 illustrates the case where exportables are the most labor intensive good. [See Corden and Neary (1982) for an application of this diagram to a Dutch-disease type of analysis.] In this diagram non-tradeables isoquants are drawn from origin $\mathrm{O}_{\mathrm{N}}$. At the initial prices the non-tradeable goods market clears at a level of production given by isoquant $\mathrm{NN}_{0}$. The capital-labor ratio in non-tradeables production is given by the slope of $\mathrm{O}_{\mathrm{N}} \mathrm{O}_{\mathrm{M}}$. Production of exportables is measured from $O_{X}$, and that of importables by distance $0_{M^{R}}$. In equilibrium the slope of $\mathrm{NN}_{0}$ lsoquant at $\mathrm{O}_{\mathrm{M}}$ equals the slopes of the corresponding isoquants for exportables and importables, which are tangent at $R$.

The discussion regarding factor rewards and relative prices (Figure 3.1) showed that the reduction of the tariff will generate, in the long-run, an increase in the wage rate relative to the rental rate. That means that all three sectors will now become more capital intensive. This is shown in

$51 /$ Notice then that theoretically depending on the assumptions regarding capital-labor intensity the real-exchange rate, defined is the domestio relative price of tradeables to non-tradeables may either increase or decline. 
Figure 3.2

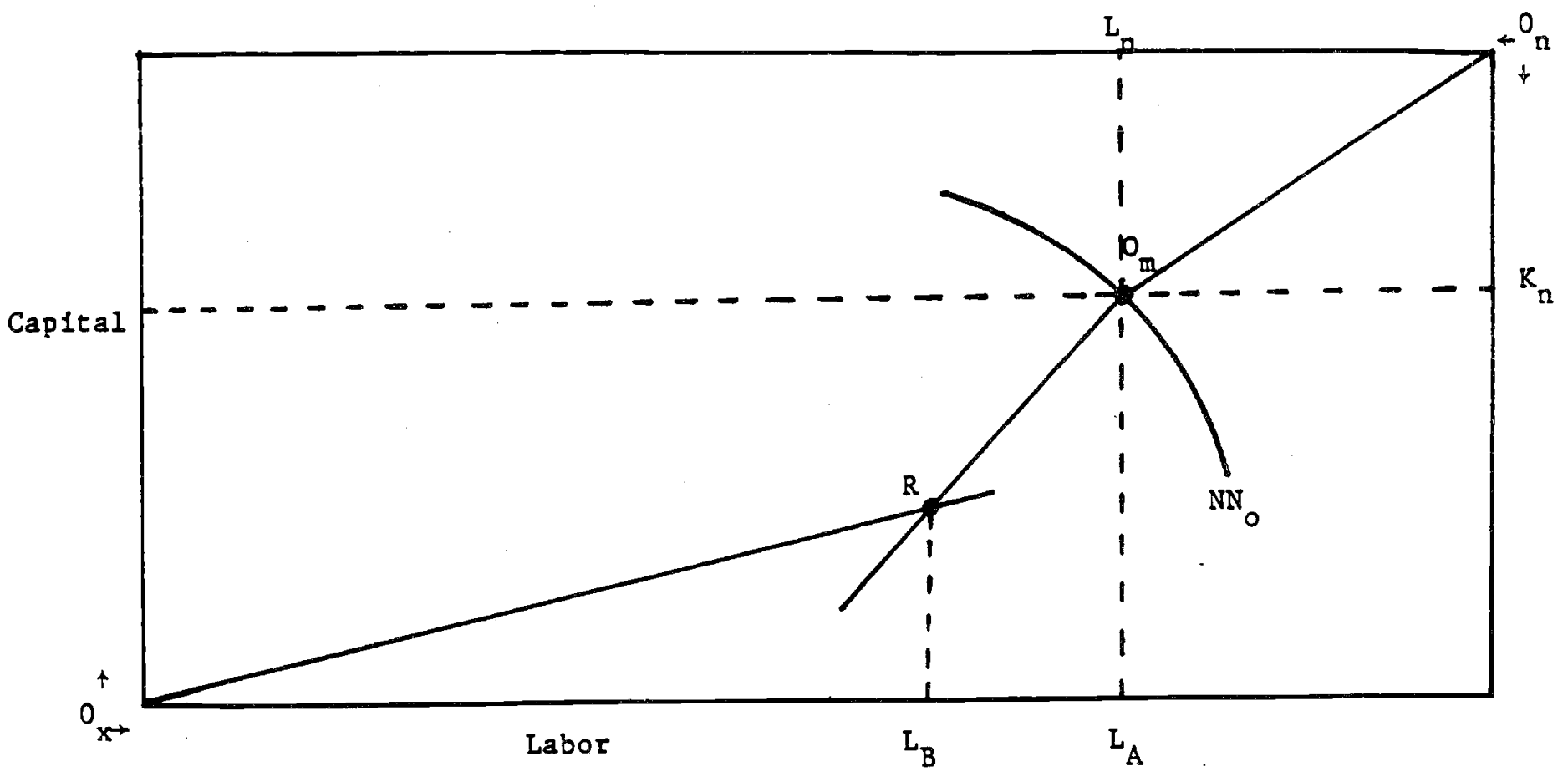


Figure 3.3 , where the dashed rays depict the new (after tariff reduction) capital/labor ratios. However, in order to determine the new equilibrium it is necessary to know what will happen to the demand of non-tradeables, as a consequence of the tariff reduction.

Assume first, in order to organize the discussion,that the quantity demanded for non-tradeables does not change after the imports tariffs are reduced. This assumption will be relaxed later. In this case, the new equilibrium point in production of non-tradeables will be obtained at the intersection of the new (higher) capital-labor ratio and the initial $\mathrm{NN}_{0}$ isoquant, at point $O_{M}^{\prime}$. Production of importables will be reduced to $O_{M}^{1} T$, and production of exportables will increase to $\mathrm{M}_{X} \mathrm{~T}$. This result was obtained under the assumption that the quantity demanded of non-tradeables was not affected by the reduction of tariffs. In general, however, this will not be the case. Moreover, given our assumptions regarding capital/labor intensity, it is expected that the demand for non-tradeables will increase as a result of the liberalization. The reasons for this are two: (a) As shown in Figure 3.1, after the liberalization of trade the (relative) price of non-tradeables will decline, producing a substitution effect in demand towards non-tradeables; and (b) the trade liberalization will generate a positive income effect, as national income at international prices increases, which will also have a positive effect on the quantity demanded of $N$. If the demand for nontradeables increases, long-run equilibrium in Figure 3.3 will be on the new capital-labor ratio ray to the left of the $\mathrm{NN}$ isocost. In terms of Figure 3.3 this new equilibrium is obtained at $O_{M}^{\prime \prime}$, with production of exportables being equal to $O S$, production of importables having been reduced to 0 SS and production of non-tradeables being equal to $\mathrm{O}_{\mathrm{N}} \mathrm{O}_{\mathrm{M}}^{\prime \prime}$ 
Figure 3.3

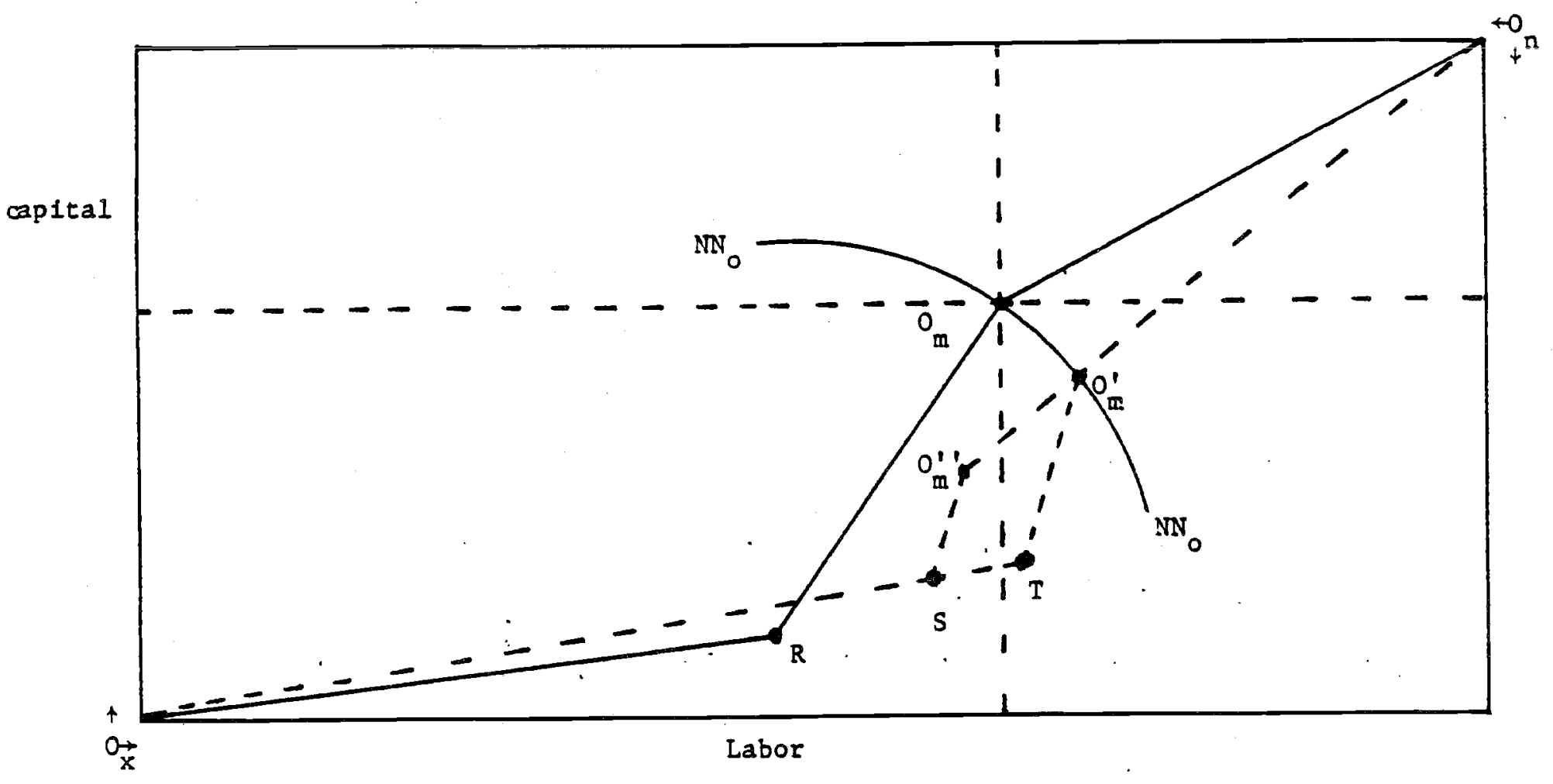


In summary, under Case 1 capital intensity assumptions, the long-run effects of a tariff reduction will be:

(i) Prices of non-tradeables, relative to exportables will fall.

(ii) Wages, relative to all goods, will increase.

(iii) The rental rate of capital, relative to all goods, will decrease.

(iv) Production of exportables will expand.

(v) Production of non-tradeables will expand.

(vi) Production of importables will decline.

\subsubsection{Short-Run Effects}

This section investigates the short-run effects of a tariff reduction under the Case 1 assumptions about capital labor intensity. It is assumed that in the short-run capital is sector specific, while labor can move freely across sections. The representation used in this model, then, is an adaptation for a three goods case of the Viner-Ricardo models of Jones (1971), Mayer (1974) and Mussa (1974). [See the paper by Corden and Neary 1982, for an application of this kind of model.]

The initial equilibrium situation can be illustrated using Figure 3.4, which is adapted from Mussa (1974) for the case of the three goods. In this figure, the horizontal axis measures total labor available in the economy, while the vertical axis depicts the wage rate in terms of exportables. $L_{T}$ is the denand for labor by the tradeable goods sectors and is equal to the (horizontal) sum of the demand for labor by the exportable sector (which is given by $L_{x}$ in this figure) and the demand for labor of the importables sector. $L_{N}$ on the other hand is the demand for labor of the non- 
tradeable goods sector. The initial equilibrium is characterized, then, by a wage rate equal to $W_{O}$, with $O_{T} L_{A}$ labor used in the production of exportables, $L_{A} L_{B}$ labor used in the production of importables and $\mathrm{OL}_{B}$ used in the production of non-tradeables.

There are several differences between this short-run model and the long-run model discussed in the previous sub-section. First, since capital is now sector specific, the direct link between tradeable goods prices and factors rewards is broken. For this reason Stolper-Samuelson theorem does not hold (in the short-run), and the price of non-tradeables will be determined by the intersection of the demand and supply schedules for these kind of goods. The strategy is now to analyze the short-run effects of trade liberalization on prices, production, resource movements and income distribution, (i.e., factor rewards). This analysis is then combined with the long-run results already discussed in the previous section to find out the characteristics of the transition, in a way similar to that proposed by Peter Neary (1978). In the short run, the reduction of the tariff, under the assumption of sector-specific factions, will generate changes both in the (relative) price of importables and non-tradeables (see, for example, Dornbusch 1974, 1980). While the price of importables will unambiguously fall, the behavior of the price of non-tradeables will depend on the assumption regarding substitutability and the magnitude of the income effects. Assuming that the three goods are gross substitutes in consumption and production, and that the income effect does not exceed the substitution effect, it can be shown that as a result of the reduction of the tariff the price of non-tradeables will fall relative to that of exportables and increase relative to that of importables. 
Figure 3.4

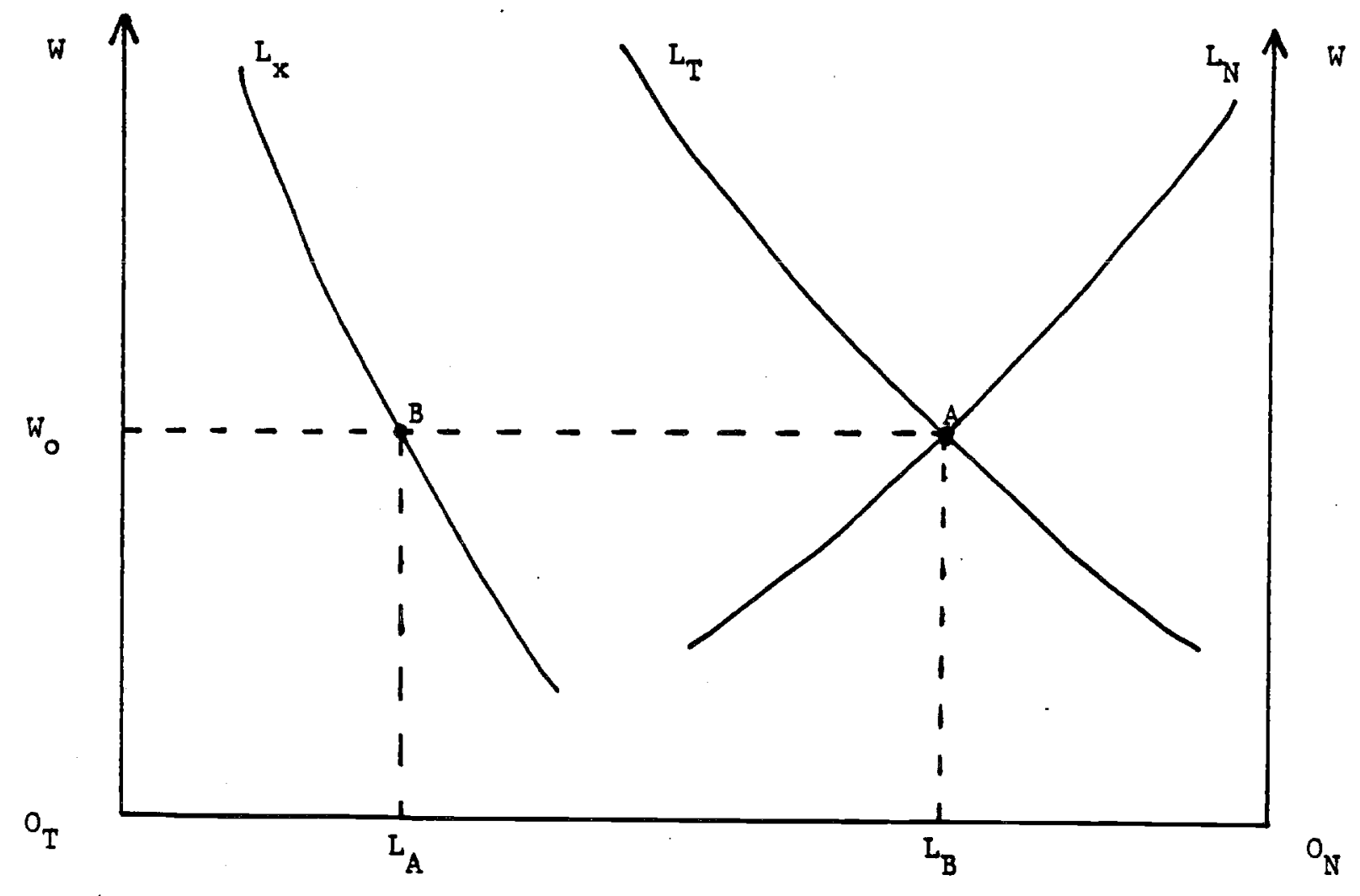


The reduction in the level of the tariff will reduce the domestic price of importables, generating a downward shift of the $L_{T}$ curve (with the $\mathrm{L}_{\mathrm{X}}$ curve constant). In Figure 3-5 the new $\mathrm{L}_{\mathrm{T}}$ curve will intersect the $L_{N}$ curve at $R$. However, this is not a final equilibrium situation, since, as already discussed the tariff reduction will also result in a decline in the price of non-tradeables (relative to exports). As a consequence, $\mathrm{L}_{\mathrm{N}}$ will shift downward (by less than $L_{T}$ ) and final short-run equilibrium will be achieved at $S$. In this new equilibrium, production of exportables has increased -- with labor used by this sector increasing by $L_{A} L_{Q}$. The production of non-tradeables may either increase or decrease, and production of importables will fall. In the case depicted in Figure 3.5 labor has moved out of importables goods sector, into exportables and non-tradeables sectors. What has happened to factors rewards in the short-run? Wages have declined in terms of the exportable good (from $W_{0}$ to $W_{1}$ in Figure 3.5 ). Also, wages decline in terms of the non-tradeable good, since the vertical distance between the $\mathrm{L}_{N}$ and $\mathrm{L}_{N}^{l}$ curves is smaller than the reduction of $W$ from $W_{0}$ to $W_{1}$ [see Mussa 1974]. However, wages increase relative to the importable good, since the domestic price of importables has fallen by more than wages. In the exportables sector, the rental rate of capital will increase in terms of all three goods, while the rental rates of the capital decrease. 521

52/ Formally, the rental rate of capital specific to the jmportable sector will decrease in terms of importables, and could either increase or decrease in terms of the other two goods. With respect to capital specific to the non-tradeables sector, its rental rate will in terms of non-tradeables, and could either increase or decrease in terms of the other two goods. 
The above discussion has assumed that all prices (of goods and factors) are fully flexible. However, this needs not be the case. In a number of countries the labor market is usually characterized by the existence of (real) minimum wages. It is easy to see from Figure 3.5 that if wages, expressed in terms of exportables are inflexibly downward, short-run unemployment will result as a consequence of the reduction of tariffs. In terms of Figure 3.5 , the magnitude of this unemployment will be equal to distance FG. This unemployment will only be a short-run phenomenon, which will tend to disappear as capital moves between sectors in the medium and long-run. $\underline{53}$ ' In general, in the presence of sector specific capital and wage rigidity in the short-run, there will be a second-best argument for slow trade liberalization and adjustment assistance. The first-best policy, however, is to act directly on the labor market, removing the sources of wage rigidity. 54 I

Under the assumption of wage flexibility, the short-run effect of trade liberalization on the levels of production can be depicted in Figure 3.6. The initial (pre-reform) equilibrium is given by points $A$ and $G$, with production of exportables proportional to distance $\mathrm{O}_{x} \dot{A}$, production of non-tradeables given by isocost $\mathrm{NN}_{0}$, and production of importables

53/ See Neary (1982) and Edwards (1982) for discussions regarding trade liberalization, sticky wages and unemployment. It is interesting to note that an effect of this type can be used to analytically derive short-run output losses following a trade liberalization process, as is done by Khan and Zahler (1983).

$54 /$ In the specific case of Chile, the tariff-reform proceeded at the same time as the minimum wage was raised in real terms. Elsewhere I have computed that the combination of the tariff reduction process and the increase in the minimum wage in chile resulted in an increase in the $r$ ate of unemployment in Chile of approximately -- percentage points. See Edwards (1982). 
Figure 3.5

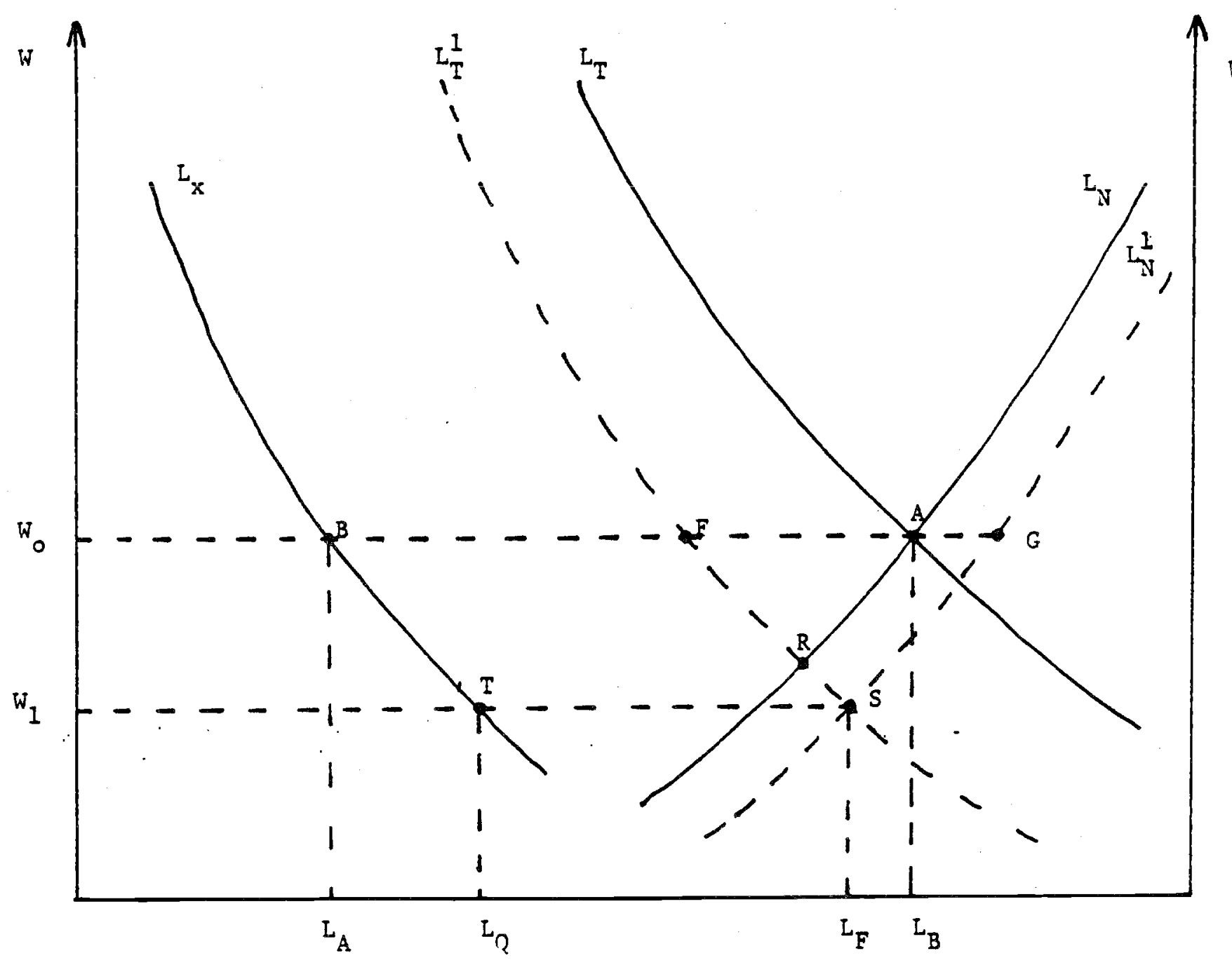


proportional to distance GA. Notice that initially the nontradeable goods sector uses $0_{N} K_{N}$ capital, the exportables sector uses $0_{x} K_{x}$ capital, and the importables will use the rest $\left(K_{\mathrm{N}} \mathrm{K}_{\mathrm{x}}\right)$. Since in the short-run capital is sector specific these amounts of capital will also be used by each sector after the tariff reform. This means that the new short-run equilibrium points will necessarily lay on the $\mathrm{K}_{\mathrm{N}} \mathrm{K}_{\mathrm{N}}$ and $\mathrm{K}_{\mathrm{x}} \mathrm{K}_{\mathrm{x}}$ lines.

The tariff reduction will result in an increase in the use of labor (and thus in production, for given amounts of capital) in the exportables and importables sectors. This is shown in Figure 3.6 by the movement of the equilibrium points to $B$ and $F$. The new capital-labor ratios are now given by the dashed lines, and as may be seen both the exportable and nontradeable sectors become relatively more labor intensive, while the importables sector has become more capital intensive. A comparison of Figures 3.3 and 3.6 provides some indication on how the transition period will look like, with factors moving from their post-reform short-run allocation (Figure 3.6) towards thair long-run post-reform allocation (Figure 3.7).

In summary, for the general case with wage flexibility, the short-run effects of a tariff reduction on production, prices, and factors rewards are the following:

(i) Production of exportables increases.

(ii) Production of importables is reduced.

(iii) Production of nontradeables increases.

(iv) Wages increase in terms of importables, and decline in terms of exportables and nontradeables

(v) The rental rate of capital in the exportable sector increases relative to all goods. 
(vi) The rental rate of capital in the importables sector will decrease relative to the importable good. It could increase or decrease relative to the other goods.

(vii) The rental rate of capital in the non-tradeables sector will increase relative to non-tradeable goods, and could elther increase or decrease relative to the other two goods.

\subsubsection{The Transition Period After a Trade Liberalization}

According to the model used in this section the main difference between short- and long-run effects of a trade liberalization is that in the short-run capital is locked into its sector of origin. As time passes, however, capital will (slowly) move between sectors. In the present model, and in order to simplify the exposition, we assume that the movement of capital does not require the use of resources. However, the analysis could be modified by introducing a "moving industry", which uses labor and some specific factor, as in Mussa [1978].

The transition period will be basically characterized by factors (both capital and labor) moving between sectors, until the new long-run equilibrium (i.e., post-liberalization) capital-labor ratios and levels of production are attained. As discussed in section 3.2.1, and as may be seen from Figure 3.3, in the final long-run equilibrium all sectors will be more capital-intensive, with the exportable sector using more capital, in absolute terms; and with the importable sector using less capital in absolute terms than prior to the trade reform. As may be also seen from Figure 3.3 , the nontradeable goods sector could use either a larger or small absolute amount of capital than before the tariffs reduction. The nature of factors movements during the transition period can be seen in Figure 3.7, which combines Figures 3.3 and 3.6. Initial (i.e., pre-liberalization) equilibrium is given by 
F1gure 3.6

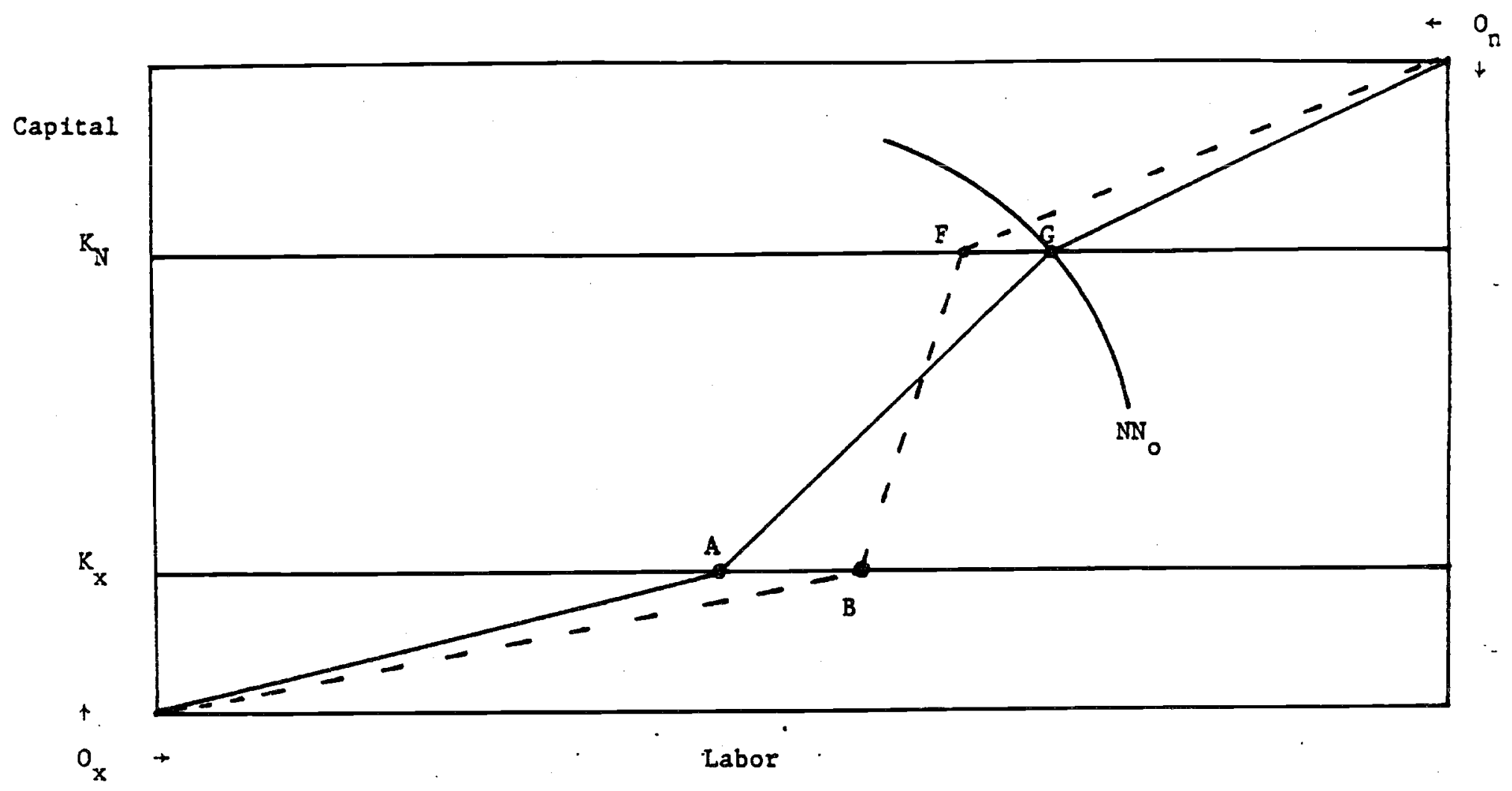


points $A$ and $G$. Short-run equilibrium is given by points $B$ and $F$; while long-run equilibrium will be attained in points $H$ and $C$. In order to avoid cluttering the diagram, only the post-liberalization capital-labor ratios have been drawn. The arrows between points $B$ and $C$ and $F$ and $H$, respectively, show the way resources will move during the transition. As may be seen in Figure 3.7, for the particular case considered here, the transition will be characterized by:

(i) Capital and labor will move out of the importable goods sector;

(ii) Capital and labor will move into the exportable goods sector;

(iii) Capital will move into the nontradeable goods sector, and labor will move out of the nontradeable goods sector.

Table 3.1 summarizes the movement of resources that follows a trade liberalization. Column (1) depicts the movement of resources in the shortrun. Column (2) shows how resources move in the long-run, when compared with the initial situation. This column is a summary of the situation described in the Melvin-Edgeworth-Bowly box in Figure 3.3. Finally, in column (3) the movement of resources during the transition period'is presented.

An important question that has not been discussed yet is related to the timing of these prices and resources movements. Broadly speaking, it would be expected that following a tariff reduction some time would pass before goods arbitrage will result in relative prices adjustments. In that sense the initial effect of tariff reductions on resource movements will not be instantaneous. $55 /$ on the other hand, it is difficult to know a priori,

55/ From a practical point of view there are a number of considerations, like the creation of the required infrastructure to increase imports, that tend to indicate that the actual reduction in domestic prices will take more time. 
Figure 3.7

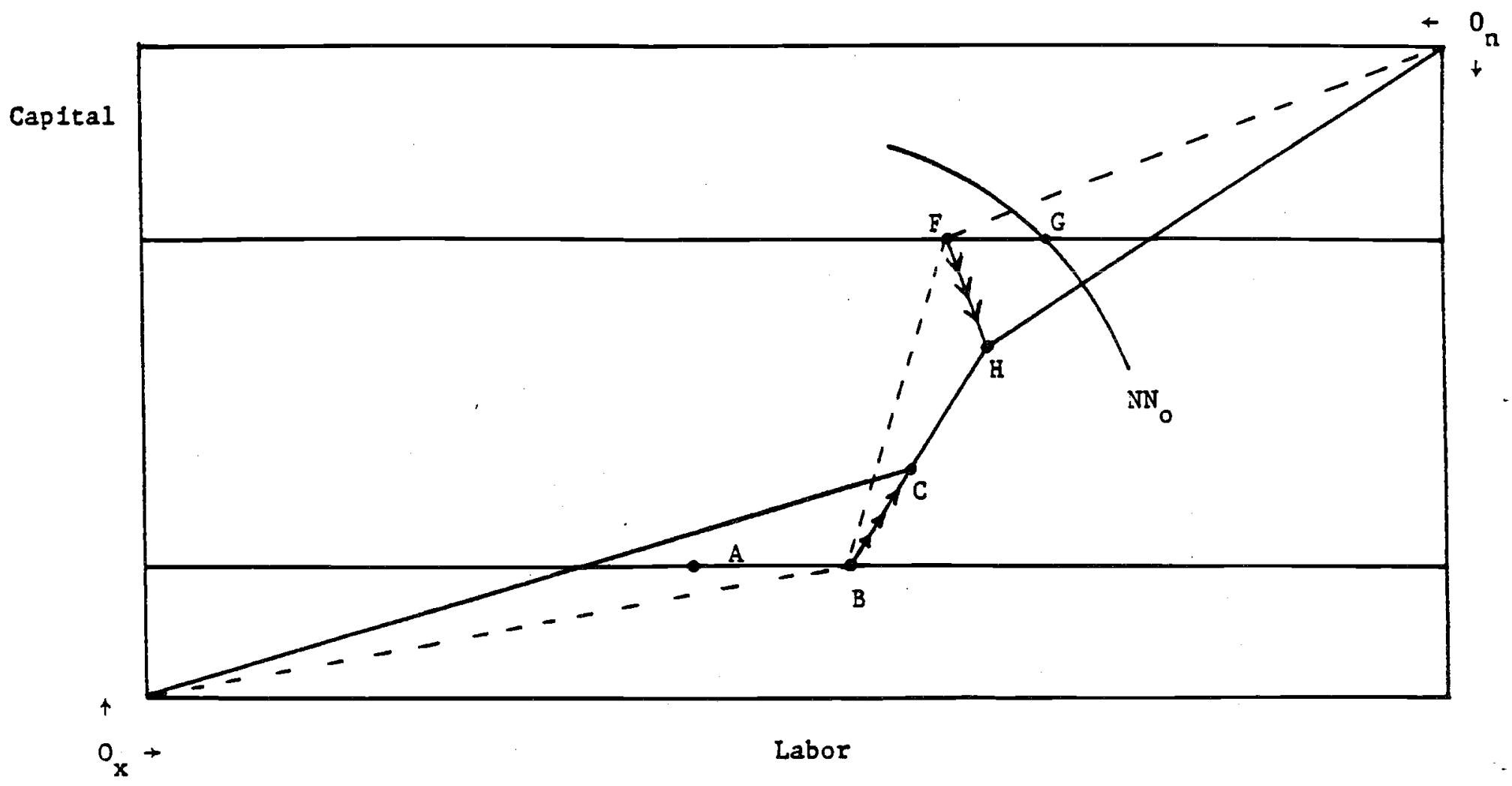


how fast the adjustment process between the short- and long-run will take. This is largely an empirical question whose answer will require countryspecific analyses.

\subsection{The Liberalization of the Capital Account}

In this sub-section the model presented above is used to investigate how the opening of the capital account (only) will affect relative prices, income distribution, production and resource movements. The analysis assumes that the importables sector is subject to a tariff and that the world relative price of exportables and importables is constant, so that these two goods can be aggregated into a single tradeable good.

It is clear that the framework used in this section (a 3 goods-2 factors model) is not the most appropriate one to deal with intertemporal problems related to the financial sector, as those generated by the opening of the capital account. However, this model is still rich enough to allow us to investigate how the opening of the capital account will affect the real side of the economy. $26 /$ In order to do this, an approach similar to that suggested by McKinnon [1976] for analyzing a transfer related adjustment is used. It is assumed that prior to the opening of the capital account the domestic rate of time preferences exceeds the world rate of interest. This means that once the capital account is opened, domestic agents will borrow from abroad in order to increase present consumption. It is further assumed that all of the foreign funds obtained, once the capital account is opened are

\footnotetext{
56/ Ideally one would want a fully specified multi-period general equilibrium model of both the real and financial sectors of the economy. Clearly, however, a model of this kind is not analytically tractable. An alternative way to tackle the problem of the opening of the capital account is to use a simulation framework as in Khan and Zahler (1983).
} 
Table 3.1

\section{Short- and Long-Run Resource Movements Following}

\section{A Trade Liberalization}

(1)

Short-Run

vs.

Sector

Exportables

Importables

Nontradeables
(2)

Long-Run

vis.

Initial Situation

K

$\uparrow$

$+$

$\uparrow$

L

$+$
(3)

Long-Run

vs.

Short-Run

(Transition)

K L

$\uparrow+(?)$
K L

$\downarrow \uparrow$

$+\uparrow(?)$ 
used to increase present consumption. 57/ Even though this is not a very realistic assumption, it simplifies the exposition. The case where the funds obtained when the capital account are used to increase investment is discussed in the next section. The discussion will then focus on the adjustment problem created by the inflow of foreign capital that will follow the opening of the capital account.

The analysis presented in this section assumes that once the capital account is opened, foreign capital will flow into the domestic economy at a stable rate for some time. This means that during a certain period of time expenditure will exceed income and foreign debt will be accumulated. 58/ For expositional convenience this discussion does not deal specifically with the following stage, where the foreign debt has to be paid. However, the analytical tools developed here can easily handle this stage of the problem. It is possible to say, then, that in this section the time horizon for the analysis has been broken into three distinct runs: the short-run, characterized by positive foreign borrowing, and sector-specific capital; the long-run, where there still is a positive inflow of foreign funds, but where capital can move between sectors; and the long-long-run (not specifically considered), where the foreign debt begins to be repaid. $\underline{59}$

57 We abstract, then, from the issues related to welfare reducing investment discussed in Section 2.2. See, however, Section 4.

58/ This idea responds to the notion, developed by Fischer and Frenkel (1972a, $1972 b)$ among others, that there are stages of the different accounts of the balance of payments through which contries pass. In that sense, then, we assume that our country is in the stage of development where foreign debt is accumulated.

$59 /$ Of course, once the foreign debt has to be repaid the analysis will be similar to what is discussed here, in the sense that a distinction between the period when capital is sector-specific and when it can move across sectors has to be made. 
The basic effect of opening the capital account is that expenditure will exceed income during some period of time. In order to simplify the discussion the core of this sub-section assumes that the amount by which expenditure exceeds income (i.e., the current account deficit) is the same in every period. However, the case where there is an initial overshooting of the level of capital inflows, as discussed in Section 2.2, is also briefly investigated. The relevance of this latter case stems from the fact that it has generally been observed that following an opening of the capital account there is a jump, and consequent reduction (i.e., an overshooting), of the level of capital inflows (for example, Korea 1965; Chile 1980; Argentina 1978; Uruguay 1979).

\subsubsection{Long-Run Effects}

In the long-run -- when capital can move between sectors -- relative prices of the three goods are completely given by world prices, technology and the tariff [see the discussion in section 4.2]. 60/ For this reason, in the present model the opening of the capital account will have no long-run effect on relative prices of goods or factors. However, to the extent that a fraction of the new funds obtained from abroad are used to finance a higher consumption of non-tradeables, the production of these goods will increase. Since a higher production of $\mathrm{N}$, requires an increase in the amount of

60/ However, as will be discussed below, in the short-run there will be changes on relative prices, zenerated by demand effects. 
$-55-$

Figure 3.8

:apttal

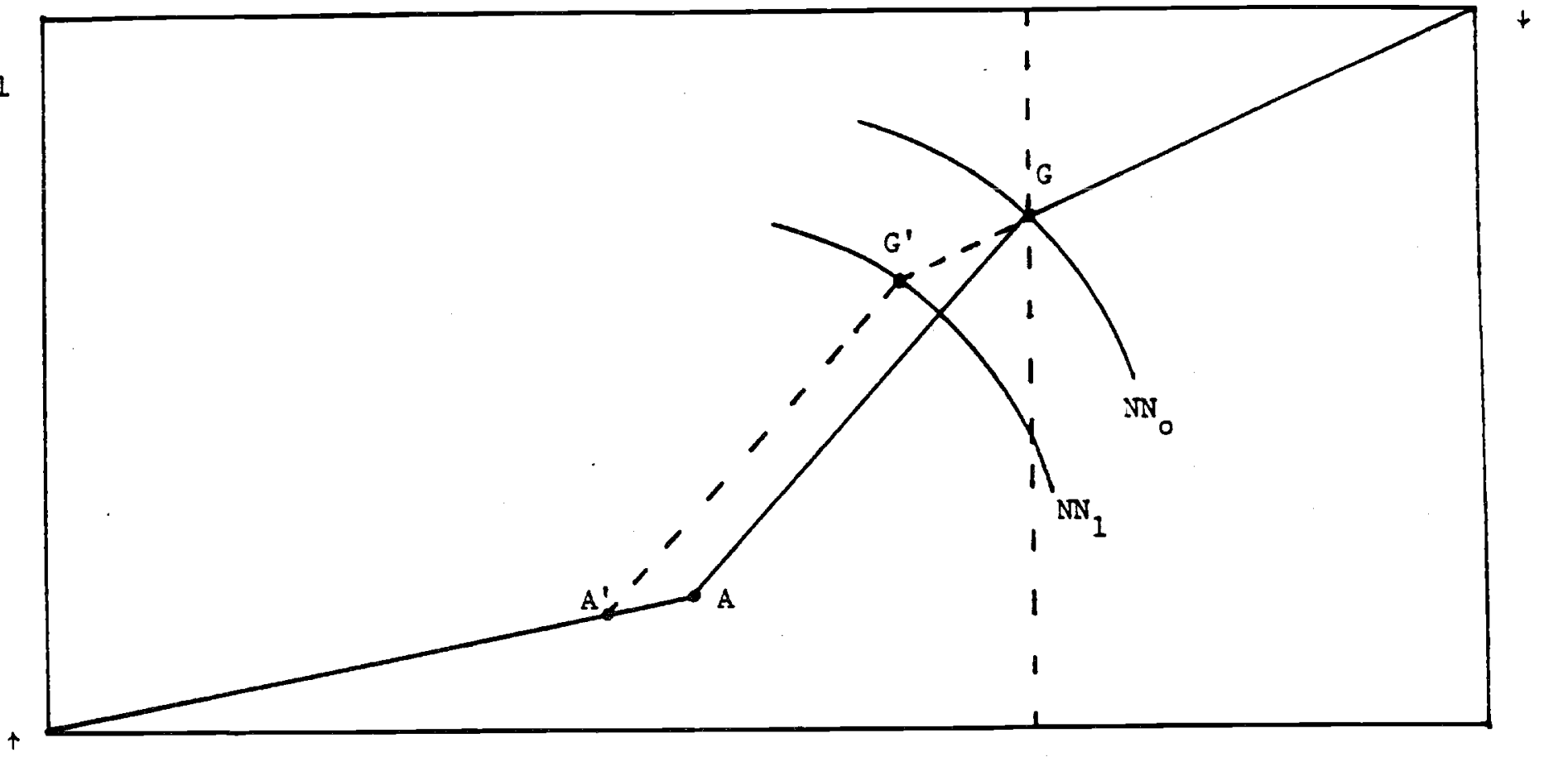

$\mathrm{O}_{\mathrm{x}} \rightarrow$

Labor 
resources used in that sector, production of the two tradeable goods will have to decline. The long-run effects of the opening of the capital account on production can be summarized in Figure 3.8, which is a by-now Pamiliar MelvinEdgeworth-Bowley box. The initial equilibrium conditions are summarized by points $G$ and $A$. Since in the long-run the opening of the capital account has no effect on relative prices or factors rewards, the original capitallabor ratios are not altered. The increase in the demand for nontradeables, however, requires a higher production of this type of goods. The expansion of the nontradeable goods sector will then take place along the original capital labor ratio $\mathrm{O}_{\mathrm{N}} \mathrm{G}$, with new (after liberalization) production of nontradeables proportional to distance ${ }_{0} \mathrm{G}_{1}^{1}$; and $\mathrm{given}$ by isoquant $\mathrm{NN}_{1}$; new production of exportables will be proportional to distance $\mathrm{X}_{\mathrm{X}} \mathrm{A}^{\prime}$; and new production of importables will be proportional to distance G'A'. It can then be seen that the long-run effects of opening the capital account will be the

(1) Production of nontradeables will increase, with capital and labor moving into this sector.

(11) Production of importables will decrease, with capital and labor moving out of this sector.

(11i) Production of exportables will decrease, with capital and labor moving out of this sector.

(iv) Prices of goods and factors will not be altered.

\subsubsection{The Short-Run Effects}

In the short-run, however, capital will be sector-specific, and the increase in the demand for nontradeable goods will be reflected in an increase 
of their relative price. 61/ The short-run effects of a capital inflow on production can be summarized in a Salter-type diagram, as used by McKinnon [1976] in his analysis of transfers and the adjustment problem. In Figure 3.9, the importable and exportable goods have been aggregated into a composite tradeables good. TT is the (short-run) production possibilities curve between tradeables and nontradeables and has been constructed under the assumption that when relative prices change only labor can move between sectors. Initial equilibrium is attained at point $Q$, with the trade account being equal to zero, and the nontradeable goods market in equilibrium. The inflow of capital that takes place after the opening of the capital account has the property of allowing the consumption possibilities schedule to exceed the production possibilities frontier. The new consumption possibilities schedule is equal to NT, which exceeds TT by the amount of the capital infiow, measured in terms of tradeables [see McKinnon 1970́, and Datta 1983]. After the opening of the capital account, and assuming that $O E$ is the income-expenditure path corresponding to the initial relative price, consumption will tend to move to $S$, while production will remain at $Q$. However, at this point there will be an excess demand for nontradeables goods. As a result of this, the relative price of nontradeables will increase until a new equilibrium situation, characterized by points $R$ (consumption) and $T$ (production) is attained. In this new equilibrium there is a current account deficit, and the non-tradeablo goods market is in equilibrium. We can

61/ Remember that we are assuming that the magnitude of the current account deficit is the same in the short,- and long-run. See sub-section 3.3.3, however, for a brief analysls of the case where there is an overshooting of the level of capital inflows. 
$-58-$

F1gure 3.9

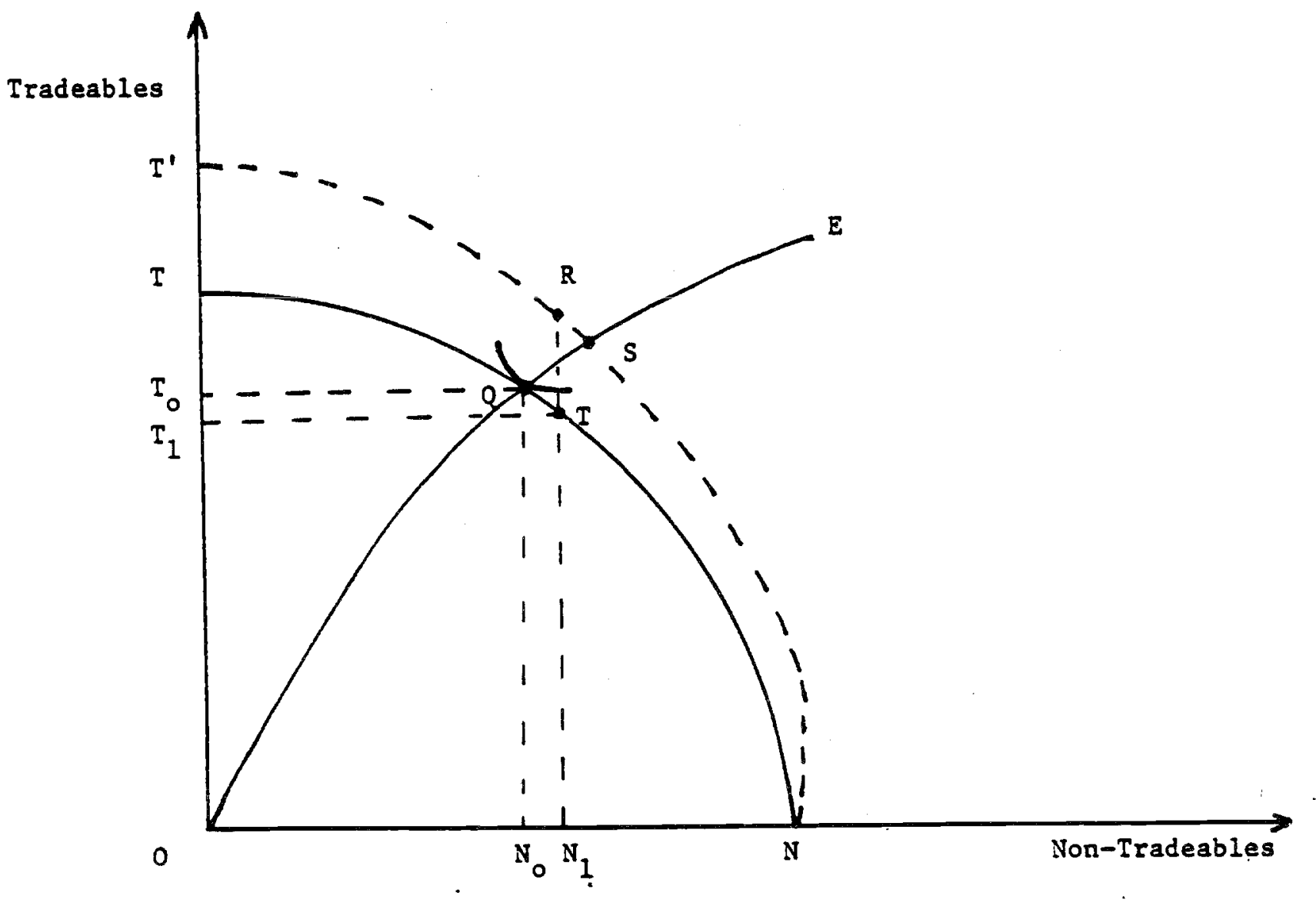


see, then, that in the short-run the opening of the capital account will result in an increase of the relative price of nontradeables relative to tradeables -- this is the real appreciation effect of opening the capital account pointed out by several authors, and discussed in Section 2.1. 62 ' The production of nontradeables will increase from $N_{0}$ to $N_{1}$, and the production of tradeables will decline from $T_{0}$ to $T_{1}$ in Figure 3.9. We can now translate the short-run effects of opening the capital account into a Melvin-Edgeworth-Bowley box. This will prove to be useful for the analysis of the transition. Figure 3.10 summarlzes the short-run effects of opening the capital account. Initlal equilibrium condltions are given by points $G$ and $A$. Once the capital account is opened, expenditure will exceed income, with production of nontradeables increasing and that of importables and exportables decreasing. New (short-run) equilibrium is attained at points $H$ and $G$, which, by definition, are characterized by the fact that the same amount of capital is used in each sector as prior to the liberalization process. However in order to increase its output, the non-tradeables sector becomes more labor intensive; while both tradeables sectors become more capital intensive.

In the short-run the wage rate increase in terms of both tradeable goods and declines in terms of non-tradeables. The return to capital specific to the non-tradeables sector goes up in terms of all goods, while the return to capital in the two non-tradeable goods declines. 63/

62/ See McKinnon (1973, 1976, 1982), Harberger (1982), Diaz-Alejandro (1981), Harberger and Edwards (1982), Cline (1983), Edwards (1984).

63/ This can be seen by following an analysis similar to that presented in Figure 3.6 . 
Figure 3.10

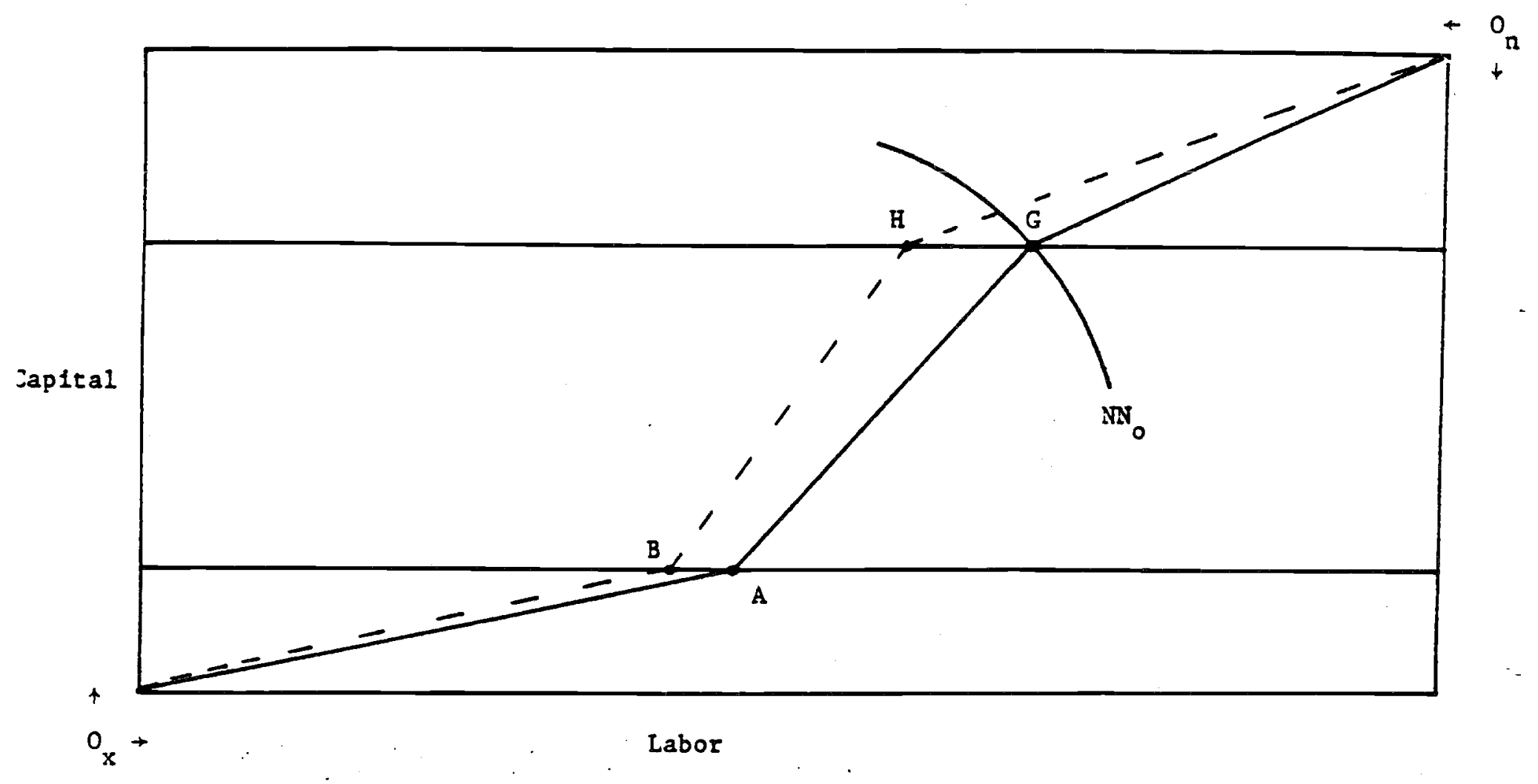


In summary, the short-run effects of the opening of the capital account are the following:

(i) Relative price of nontradeables increases in terms of both tradeable goods.

(ii) Production of nontradeables increases.

(iii) Production of both nontradeables decline.

(iv) The wage rate increases in terms of both nontradeables and declines in terms of the nontradeable.

(v) The rental rate of capital in both tradeable goods sectors declines, in terms of all goods.

(vi) The return to capital in the nontradeable goods sector goes up in terms of all goods.

\subsubsection{Transition}

As in the case of the trade liberalization, the transition will be characterized by resources moving from their short-run equilibrium (Figure 3.10) towards their long-run equilibrium (Figure 3.8). As before, the best way to look at these resource movements is by combining the short- and longrun diagrams. This is done in Figure 3.11. In this diagram $A$ and $G$ are initial (i.e., pre-liberalization) equilibrium points; $H$ and $B$ depict the short-run equilibrium after liberalization; and $A^{\prime}$ and $G^{\prime}$ are the long-run post-liberalization equilibrium points. It may be noted that in Figure 3.11 the final equilibrium level of production of $N$, given by isoquant $N_{1}$ (G') exceeds short-run level of production (given by the isoquant that passes through point $H$ ). The reason for this result is that while the income effect -- stemming from the higher absorption allowed by the opening of the capital account -- is by assumption the sane in the short- and long-run, the relative 
$-62-$

Figure 3.11

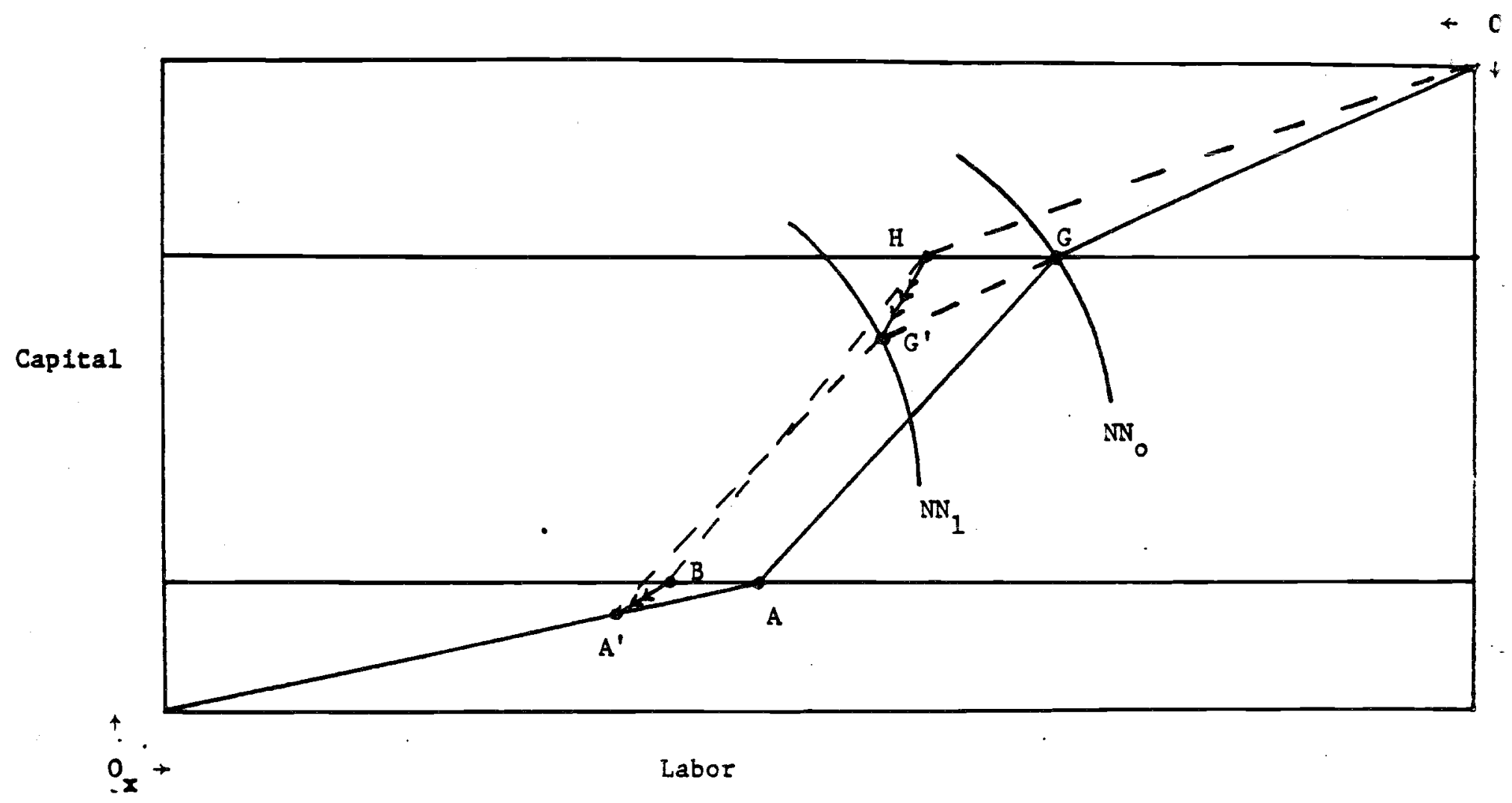


price of nontradeables is higher in the short-run. Consequently the equilibrium level of production of non-tradeables will be higher in the longrun. 64/ If, however, it is assumed that in the short-run the level of capital inflows will overshoot their long-run levels, the result will be somewhat different [see Figure 3.12 below].

Under the present assumptions -- that the current account deficit is the same in short- and long-run -- the transition will be characterized by resources moving from $H$ to $G^{\prime}$ and from $B$ to $A^{\prime}$ in Figure 3.11 . Capital and labor will move into the nontradeables sector and out of both tradeable sectors. The production of nontradeables will further expand during the transition, with the production of both tradeables declining. Table 3.2 presents a summary of the short-and long-run resource movements that will follow an opening of the capital account, under the maintained assumptions. This table is equivalent to Table 3.1 constructed for the case of the trade reform only. A comparison of both tables shows that both reforms, on their own, will tend to generate opposite movement of resources. This fact, of course, is reflected by the fact that the real exchange rate will tend to move in opposite directions under each reform.

At this point, it is important to recall some of the critical assumptions that have been made for this exercise. First, it was assumed that as a consequence of the opening of the capital account, capital would flow into the domestic country, allowing absorption to exceed income. It was further

64/ The reason for this is that while in both cases (short- and long-run) the demand curve for non-tradeables will shift to the right by the same amount, the supply curve is more elastic in the long-run. Thus, the equilibrium output of non-tradeables will be higher in the long-run. 
assumed that this situation was sustainable for a (fairly) long period of time, and that all the funds obtained from abroad were channeled into additional consumption. In that sense in this section the time horizon of the analysis was broken into three distinct lengths. The short-run, characterized by a positive foreign borrowing (absorption > income), and by capital being sector specific. The long-run, where there also is positive borrowing (absorption > income) but where capital can move between sectors; and the long-long-run when the foreign debt has to be paid. It was assumed that the long-long-run takes place in the (distant) future, and was not analyzed.

A second important assumption made here is that once the capital account is opened a stable inflow of foreign capital takes place. In that sense, the possibility of an overshooting of the level of capital flows was ignored. This is not an innocent simplification, since, as has been mentioned, the stylized facts indicate that generally following the opening of the capital account there is an initial jump in the level of capital inflows. If such a behavior of capital flows was allowed, the analysis presented here will change with more resources moving into the nontradeable goods sector into the short-run. This case is presented in Figure 3.12, where short-run production of non-tradeables -- given by isoquant $\mathrm{NN}_{2}-$ exceeds long-run production of this kind of goods (given by isoquant $\mathrm{NN}_{1}$ ). In this case the transition will differ from our previous analysis. As may be seen in Figure 3.12 , in this case while capital will move into the nontradeable sector, labor will move out of the non-tradeable goods sector during the transition.

A critical question related to he effects of opening the capital account of the balance of payments has to do with the speed at which these 


\section{Table 3.2}

Short- and Long-Run Resource Movements

Following a Capital Account Liberalization

(1)

Short-Run

vs.

Sector

Exportables

Importables

Nontradeables
(2)

Long-Run

vs.

Initial Situation

$\underline{L}$

$\cdot$

$\downarrow$

$\downarrow$

$\uparrow$
$\underline{\mathrm{K}}$

$\downarrow$

$\uparrow$
(3) Long-Run vs. Short-Run (Transition)

$\underline{\mathrm{K}} \underline{\mathrm{L}}$

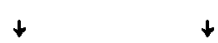


price and resource movements will take place. In general -- and as has been emphasized by Frenkel [1982, 1983] -- it is expected that the inflow of capital following the opening of the capital account will be fast. In that case then, it is expected that the short-run consequences of liberalizing this account of the balance of payments -- in particular the increase of the relative price of $\mathrm{N}$ and the tendency for labor to move into this sector -will be felt quickly. In fact, as will be argued below, and has been suggested by Frenkel [1983], the difference in the speed of adjustment of the capital and current account suggests that an appropriate order will consider opening the current account first. It will also be argued that the capital account should be opened slowly, following a multi-stage procedure.

\section{4 Summary}

This section has presented a three-goods two-factors model to analyze the real effects -- i.e., production and income distribution effects -- of the liberalization of the current and capital account of the balance of payments. The analysis presented provided details on the characteristics of these processes, comfirming prior conjectures: each reform on its own will result in opposite effects on resource movements and income distribution.

Abandoning the sphere of positive analysis, a critical question at this stage is if there is anything to be learned regarding the appropriate order of liberalization from this discussion? The answer to this question is a qualified yes. To the extent that. in the real world resource movements across sectors are costly, there i 3 a reason to try to avoid "unnecessary" 
shifts in resources. 65/ A possible instance where these kind of costs will occur will emerge if, for example, due to a given policy labor and capital move out of the exports sector, and shortly afterwards, due to a different policy labor and capital have to move back into this sector. These "unnecessary" adjustment costs could be avolded if resources are directly reallocated into their final sectors of use. This could be achieved by synchronizing the openings of the capital and current accounts as has been suggested by Frenkel (1983). At this point it could be argued that the principles of reducing the adjustment costs would call for a simultaneous opening of both accounts. In this case, the argument would go, resources would move directly into their final sectors without "unnecessary" switches. The problem with this reasoning, however, is that 1 t implicitly assumes that the adjustment process following the opening of these accounts is equally fast. If however, this is not the case, and the adjustment of the capital account is faster -- as Frenkel 1982, 1983, Khan and Zahler (1983) and others have suggested -- the simultaneous opening of both accounts will result in resources moving first into the non-tradeable goods sector and out of exportables and importables. In other words, if both accounts are opened simultaneously, in the short-run the capital account effects will tend to dominate. If the capital account adjusts faster, 66/ the avoidance of

65' A possible way to model moving costs is through the existence of a "moving sector" as in Mussa (1978).

66/ In terms of this model a faster adjustment of the capital account means that interest arbitrage is faster than good arbitrage, and that immedlately following the opening of the capital account resources will be borrowed and absorption will exceed absorption. On the other hand, following trade reform some time will pass before goods arbitrage will result in resource investment. 
$-68-$

F1gure 3.12

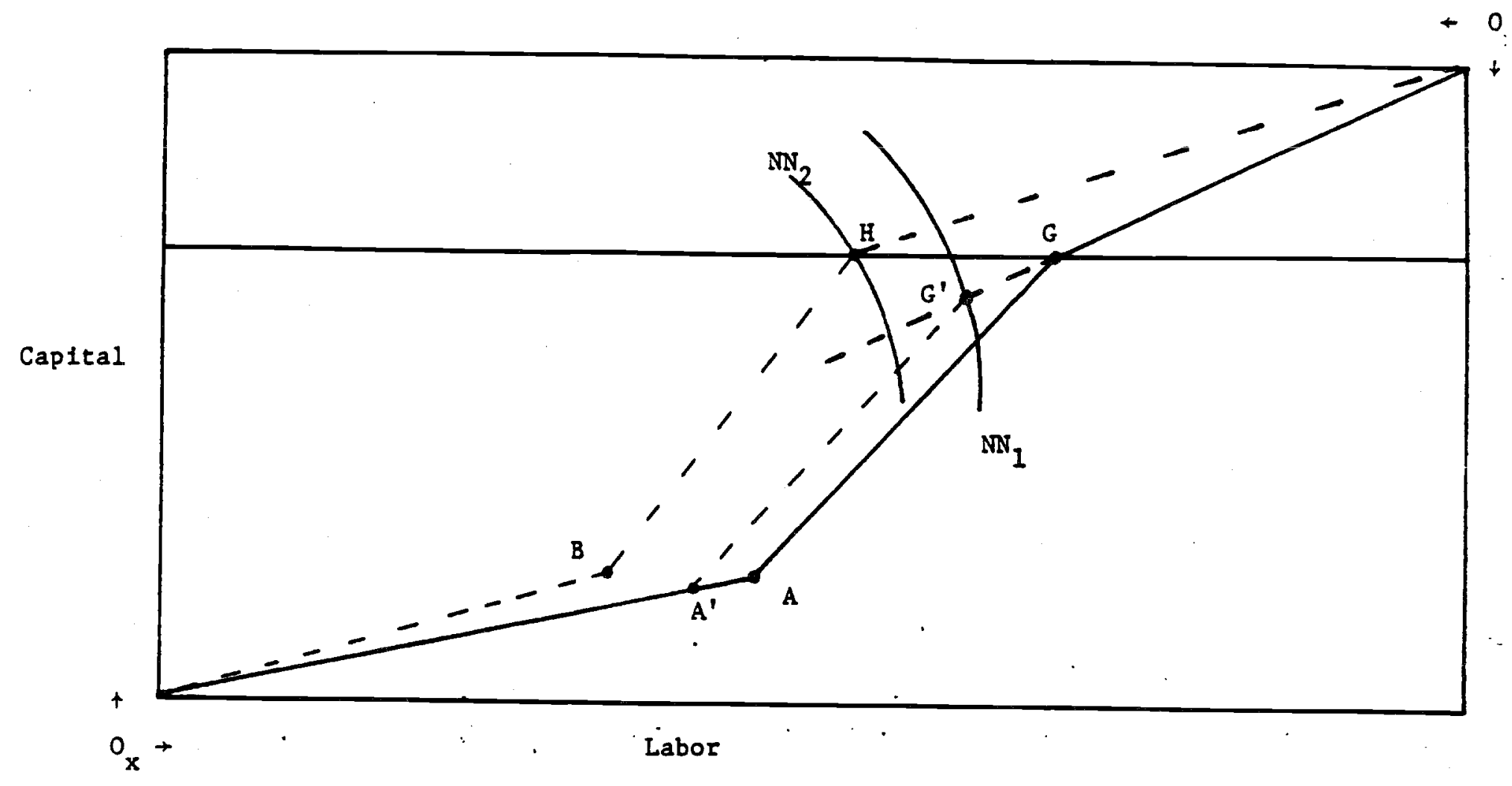


"unnecessary" adjustment costs, and the synchronization of both effects would be obtained following the order of liberalization suggested by Jacob Frenkel (1982, 1983): the current account should be opened first, and only when this is open should restrictions on capital movements be restricted.

\section{Welfare Implications of Opening The Capital Account in the Presence of Trade Distortions}

As discussed in Section 2 above, one of the arguments that has been used to suggest that the trade account should be liberalized first is that if capital inflows are allowed in the presence of trade distortions (i.e., tariffs) welfare losses will result [McKinnon 1973; Frenkel 1982, 1983;

Krueger 1983]. In this section this proposition is investigated in detail using a multi-period general equilibrium model of a small open economy. 67 ' First we investigate the welfare effects of allowing foreign borrowing in an economy without trade distortions. The results obtained are, of course, the standard ones: welfare will increase if prior to the liberalization of the capital account the domestic consumption rate of interest exceeds the world rate of interest. Next we introduce tariffs into the plcture and investigate the welfare effects of opening up the capital account in the presence of trade distortions. The analysis shows, as it was suggested in Section 2.2, that the welfare effects of opening the capital account will depend on how the funds obtained are used. If these resources are used to increase present consumption, and the domestic consumption rate of interest exceeds the world rate of

$67 /$ Much of the discussion in this section draws from Section 3.1 of a joint paper with Sweder van Wijnbergen. See Edwards and Van Wijnbergen (1983). 
interest, the opening of the capital account can never be welfare deteriorating. If, however, these funds are used to finance capital accumulation, welfare may deteriorate as long as the importable goods is capital intensive. As discussed in section 2.2, this is a direct extension of the literature on welfare-reducing capital accumulation in a static framework. $68 /$

An important question regarding this Iine of argument is the following: Why would the resources borrowed from abroad be used to accumulate capital, if society's welfare will be reduced? The answer is that, while socially capital accumulation might be immiserizing (since it increases a preexisting distortion), privately it may be profitable. Indeed this will be the case since, under the assumptions of capital intensive importables, due to the presence of tariffs the marginal product of capital in the domestic country will exceed the world marginal product of capital [Stolper and Samuelson 1943]. It is also possible to show that if shadow prices are used to make investment decisions the opening of the capital account can never result in welfare reductions [Edwards and van Wijnbergen, 1983].

\subsection{The Model}

The model assumes a two-period world where total welfare depends on the levels of utility obtained in periods 1 and 2 respectively. If for eign borrowing is not allowed, in each period the budget constraint has to hold,

68/ See, for example, Johnson (1967), Bertrand and Flatters (1971) and Brecher and Diaz-Alejandro (1977). 
with total expenditures being equal to total revenues. In this section a general version of the model (with trade distortions) is presented. In Section 4.2 the welfare effects of opening the capital account (1.e., allowing a small amount of foreign borrowing) is investigated under the simplifying assumption of no-trade distortions. In section 4.3 the assumption of trade distortions are reintroduced into the analysis. $69 /$

It is assumed that there are two goods in the economy ( $\mathrm{X}$ and $\mathrm{Y}$ ). Good $X$ is taken to be the numeraire and is assumed to be the exportable (1.e., the labor intensive good). It is also assumed that prior to opening the capital account the domestic consumption rate of interest exceeds the world rate of interes $\left(r^{*}\right)$. The essentials of the model, under the assumption that foreign borrowing is forbidden are presented in equations (4.1) through (4.8), where throughout the analysis a super index $i$ refers to the $1^{\text {th }}$ perlod. [For analyses using this kind of model see, for example, Svensson and Razin 1983; Van Wijnbergen 1984; and Edwards and van Wijnbergen 1983]. $70 /$

69/ In some sense the effects of opening the capital account can be analyzed as a two-way transfer, where the domestic country recelves a transfer in the first period and gives a (larger) transfer in the second period.

70/ See Dixit and Norman (1980) for a clear exposition of the use of duality in trade analysis. See Mussa (1379) for a geometric exposition. 


$$
\begin{aligned}
& W=W\left(U^{1}, U^{2}\right) \\
& U^{1}=U^{1}\left(X^{1}, y^{1}\right) ; U^{2}=U^{2}\left(X^{2}, y^{2}\right) \\
& E^{1}=\pi^{1} U^{1} ; E^{2}=\pi^{2} U^{2} \\
& \pi^{1}=\pi^{1}\left(1, P_{y}^{1}\right) \\
& \pi^{2}=\pi^{2}\left(1, P_{y}^{2}\right) \\
& P_{y}^{i}=P_{y}^{*}+\tau \\
& R^{i}\left(1, P_{y}^{i}, K^{1}\right)+\tau M^{1}=E^{1}\left(1, P_{y}^{1} ; U^{i}\right) \quad i=1,2 \\
& M^{i}=E_{P}^{i}-R_{y}^{i}
\end{aligned}
$$

Equation (4.1) is the welfare function which is assumed to be weakly separable. The subutilities $U^{1}$ and $U^{2}$, for periods 1 and 2 respectively (equation (4.2)) are assumed to be identical and homothetic. Given the homotheticity assumptions of $U^{1}$ and $U^{2}$, the underlying expenditure functions for each period $E^{1}$ and $E^{2}$ can be written as equation (4.3), where $\Pi^{1}$ and $\pi^{2}$ [equations (4.4) and (4.6)] are "exact" price indexes and are equal to unitary expenditure functions. $71 /$ Equation (4.5) establishes that the domestic relative price of the importable $\left(P_{y}\right)$ is equal to the world. price $\left(P_{y}^{*}\right)$ plus a tariff $\tau$. Notice that by (4.6) we are assuming that prices do not change between periods 1 and 2. Even though this assumption greatly simplifies the exposition, it is not essential for the results obtained [see Edwards and Van Wijnbergen 1983, for a similar discussion where the domestic price $P_{y}$ declines in period 2 due to the reduction of the level

71/ See Dixit and Norman (1980) for the properties of an expenditure function. On exact price indexes see Svensson and Razin (1983) and van Wijnbergen (1984). 
of the tariff.] Equation (4.7) is the budget constraint for periods 1 and 2 respectively. This equation captures the assumption of a closed capital account, since it indicates that total revenues -- given by the revenue function $R$ plus tariff collection $\tau M$-- has to equal total expenditure in each period. If on the other hand a fully open capital account is assumed equations (4.7) would be replaced by a single intertemporal budget constraint. 12 Equation (4.8) defines the level of imports in every period. Total imports are equal to the difference between the quantities demanded and supplied of good $y$ in each period.

One of the simplifying assumptions of the model is that prior to the opening of the capital account there is no capital accumulation in the economy (i.e., $\mathrm{dK}_{1}=0$ ). However, it is assumed that when the capital account is opened domestic firms can borrow abroad and use the proceeds of these loans to increase their capital stock. While this is clearly a simplifying assumption it allows us to focus on the essentials. 13 /

\subsection{Opening the Capital Account in the Absence of Trade Distortions} Assume, in order, to simplify the discussion and to set up the general analytical framework, that tariffs are equal to zero: $\tau=0$. Consider now that a small amount of foreign borrowing is allowed, and that the proceeds of this loan are used to increase present consumption. Analytically we assume

72/ See van Wijnbergen (1984) for example, and Edwards and van Wijnbergen (1983).

73/ However, it is possible to interpret the results presented here as resulting from an increment in the rate of capital accumulation, which is made possible by the opening of the capital account. 
that the loan is in terms of the numeralre good. However, under the assumption of an open economy, domestic agents will obtain the desired consumption bundle through international exchange [see Dixit and Norman, 1980].

Under the present assumptions, the opening of the capital account will imply that consumption will increase in period 1 by the amount of the loan, and will decrease in period 2, by a larger amount, since principal plus interest have to be paid in that period. The effects of this operation on the levels of utility in periods 1 and 2 can be found by totally differentiating equation (4.7). The effect of opening the capital account on total welfare (W) is then found by totally differentiating equation (4.1) and by then inserting the results for $\mathrm{dU}^{1}$ and $\mathrm{dU}^{2}$.

The changes in utility in periods 1 and 2 are given by expressions (4.9) and (4.10) respectively where $d B$ is the amount borrowed in period 1 , which is fully used to increase present consumption, and where $r^{*}$ is the world rate of interest.

$$
d U^{1}=\left(1 / E_{U^{l}}^{1}\right) d B>0
$$

and

$$
d U^{2}=-\left[\left(1+r^{*}\right) / E_{U^{2}}^{2}\right] d B<0
$$

The total effect on welfare of allowing (some) foreign borrowing is then obtained by totally differentiating equation ( 4.1 ), and by using ( 4.3 ), (4.9), and (4.10).

$$
d W=\left[1-\left(1+r^{*}\right) \lambda\right]\left(\partial W / \Pi_{1} \partial U^{1}\right) d B
$$

where 


$$
\lambda=\frac{\left(\partial W / \pi^{2} \partial U^{2}\right)}{\left(\partial W / \pi^{1} \partial U^{1}\right)}
$$

is equal to the inverse of one plus the consumption rate of interest in the domestic country $(1+\mathrm{CRI}) . \underline{75 /}$ Under the assumption of closed.capital account, assuming that intertemporal substitutions is not allowed, the consumption rate of interest will exceed the world rate of interest $r^{*}$. Consequently, $\left(1+r^{*}\right) \lambda<1$ and in equation (4.11)

$$
\frac{d W}{d B}>0
$$

The opening of the capital account will be welfare improving. of course, if prior to the opening of the capital account present consumption was "too high" in the domestic economy $\lambda\left(1+r^{*}\right)$ will be smaller than one. In this case, however, the opening of the capital account will still be welfare improving since once it is opened the domestic country will lend in the world market! In that case (4.11) would be $d W=\left[\left(1+r^{*}\right) \lambda-1\right]\left(\partial W / \Pi_{1} \partial U^{l}\right) d B$. of course, what generates an improvement in welfare is to allow (some) Intertemporal substitution of consumption, which was previously banned. Assume now that once the capital account is opened, the proceeds from the foreign loans are used to increase capital accumulation in the domestic country (i.e., machines are imported). This will allow the economy to increase production in period 1. $76 /$ In period 2, however, the loan has to be paid. In order to simplify the discussion it will be assumed, at his stage of

75/ See, for example the discussion in Svensson and Razin (1983, p. 109110). See also Van Wijnbergen (1984).

76/ It is assumed that capital begins producing in the same period it is installed. Alternatively it coild be assumed that there was a one period lag. The results will remain essentially the same, however. 
the analysis, that the loan is also paid in the form of machines (i.e., disinvestment takes place in the second period).

Totally differentiating (4.7), and (4.1) the following expression, very similar to (4.11), is found -- where $R_{K}$, the partial derivative of the revenue function in respect to the stock of capital and is equal to the domestic marginal productivity of capital [see Dixit and Norman (1980)]:

$$
d W=\left[1-\left(1+r^{*}\right) \lambda\right]\left(\partial W / \pi_{1} \partial U^{1}\right) R_{K} d K
$$

Ás may be seen, alsó $i n$ this case if the consumption rate of interest. exceeds the world interest rate (i.e., $\left.\left(1+r^{*}\right) \lambda<1\right)$ the opening of the capital account -- where the proceeds from the loan are used to accumulate capital -- will be welfare improving (i.e., $d W / d K>0$ ). The main difference between (4.12) and (4.11) is that instead of $d B$ we now have $R_{K} d K$. This last term, of course, represents the increase in national income in period 1 , in terms of the numeraire good, resulting from an increase in the stock of capital equal to dK. From the comparison of (4.11) and (4.12) it follows that to the extent that the price of machines in terms of the numeraire good, (i.e., Tobin's "q") is equal to $\left(1 / R_{K}\right)$ it is indifferent whether once foreign borrowing is allowed the resources obtained from abroad are used to add one machine to the stock of capital or directly to increase present consumption. $77 /$ As will be shown in section 4.3 below this is not the case once trade distortions are allowed into the picture. the reason for this is that, while in the presence of trade distortions, the private price of

I7/ of course, this price of capital $\left(1 / R_{K}\right)$ can be used to formulate the present problem in a way such that the loan is paid in the form of goods, and not of machines. The resilt.3, however, are exactly the same as those presented here. 
machines is still $\left(1 / R_{K}\right)$, from a social perspective this price is lower and could even be negative. 18 '

4.3 The Opening of the Capital Account in the Presence of Trade

\section{Distortions}

In this section it is assumed that there is a tariff on the import of good $y$ (i.e., $\tau>0$ ), and the welfare effect of opening the capital account is investigated. Following last section's strategy it is first assumed that the proceeds from the foreign loan are used exclusively to increase present consumption.

Assume, as before, that the world rate of interest is equal to $r^{*}$. As in the previous case, consider first what happens when the proceeds from the foreign loan are fully used to increase present consumption. The effects on each period's utility of a loan obtained in period 1 and repaid (with an interest equal to $r^{*}$ ) in period 2 is now given by (4.13) and (4.14):

and

$$
\begin{aligned}
& \mathrm{dU}^{1}=\underset{\mathrm{E}^{1}}{\left(\frac{1}{\mathrm{E}^{1}}\right)}\left\{\frac{1}{\left(1-\tau \mathrm{d}_{E y}\right)}\right\} \mathrm{dB} \\
& \mathrm{dU}^{2}=\underset{\mathrm{E}_{\mathrm{U}^{2}}^{2}}{-\left(\frac{1}{\left(1-\tau \mathrm{d}_{\mathrm{y}}\right)}\right\}\left(1+\mathrm{r}^{*}\right) \mathrm{dB}}
\end{aligned}
$$

where $d_{E y}$ captures the pure income effect on the demand for $y$ resulting

78/ This corresponds to Bhagwati's et al. case of negative shadow prices. 
from changes in real income. $\frac{79 /}{}$ Since $\tau d_{E y}$ is smaller than one, (4.12) will be positive and (4.13) negative. 80 / As before, the effect on total welfare is found by totally differentiating (4.1) and using (4.13) and (4.14). The result obtained is:

$$
d W=\left[1-\left(1+r^{*}\right) \lambda\right]\left(\partial W / \pi^{l} \partial U^{l}\right)\left(\frac{1}{1-\tau d_{E y}}\right) d B
$$

which under our assumptions of $\lambda\left(1+r^{*}\right)<1$ is greater than zero. That means that in the presence of trade restrictions allowing foreign-borrowing to increase present consumption is still welfare improving.

Assume now that the private sector uses the proceeds of the foreign loans to increase its stock of capital. That would be the case if the (world) price of a machine, in terms of the numeralre good is equal or lower than $\left(1 / R_{K}\right)$. Assume in order to simplify the exposition that this price is exactly equal to $\left(1 / R_{K}\right)$. In this case the welfare effect of opening the capital account, under the assumption that the loan is also paid in the form of machines, will be given by equation (4.16):

79/ In order to derive (5.12) and (5.13) the following property was used: $d_{E y}$ $E_{u}=E_{p u}$. See Dixit and Norman (1980, p. 62).

80/ This statement can be proven in the following way: $P_{y} d_{E y}$ is the marginal propensity to spend on $y$ and consequently smaller than one. Also, since $P_{y}>\tau$ it follows that $\left(P_{y} d_{E y}\right)\left(\frac{\tau}{P_{y}}\right)=d_{E y} \tau<1$. Thus $\left(1-\tau d_{E y}\right)>1$. 


$$
d W=\left[1-\left(1+r^{*}\right) \lambda\right]\left(\partial W / \Pi^{1} \partial U^{1}\right)\left(R_{K}-\tau R_{P_{y}} K\right)\left[1 /\left(1-\tau d_{E y}\right)\right] d K
$$

where $R_{P_{y} k}$ is a Rybczynski term that captures the effect of capital accumulation on the production of the importable good. Given our assumption regarding factors proportions -- the importable good $y$ is capital intensive in our developing economy -- $\mathrm{R}_{\mathrm{P}_{\mathrm{y}} \mathrm{K}}>0$.

Equation (4.16) is interesting for several reasons. First, as may be seen it can be either positive or negative. It can be negative even if the world rate of interest is below the consumption rate of interest [1.e., $\left.\left(1+r^{*}\right) \lambda<1\right]$. This will be the case if $R_{K}<\tau R_{P_{y}} K^{*}$ This is nothing else than the Johnson [1967] condition for Immiserizing capital accumulation. 81/

Intuitively the possibility that the opening of the capital account will result in a welfare loss is easy to explain. Under the presence of tariffs there will be a difference between the private and social marginal productivities of capital. While the private marginal productivity of capital is $R_{K}$ (as it was in the absence of tariffs), its social marginal if shadow prices are used to make investment decisions this welfare reducing effect of opening the capital account in the presence of trade distortions will not arise [Edwards and van wijnbergen 1983]. Productivity is $\left(\mathrm{R}_{\mathrm{K}}-\tau_{\mathrm{P}_{\mathrm{y}} \mathrm{K}}\right)$. $82 /$

$81 /$ It is interesting to note that, contrary to the Brecher-Diaz-Alejandro (1977) one-period analysis on foreign investment, if $R_{K}>\tau R_{P_{K}}$ capital accumulation cannot be immenserizing even if $r^{*}=R_{K}$. The reason for this is that in the present intertemporal framework the important comparison is between $r^{*}$ and the consumption rate of interest, and not between $R_{K}$ and $r^{*}$.

82/ An alternative way of looking at this is comparing $R_{K}$ evaluated at domestic tariff inclusive prices, and evaluated at world prices. It is easy to show that this last expression will be equal to $\left(R_{K}-\tau R_{P} K_{y}\right)$. 
The reason for this is that capital accumulation will result in lower total imports and thus lower tariffs collection (term $\tau M$ in equation 4.1). It is possible then that the negative effect on welfare of the reduction of tariffs collections will generate an overall welfare reduction. This is a typical second best type of argument that indicates that reducing some distortions only can result in total welfare being reduced. Of course, if shadow prices are used to make investment decisions this welfare reducing effect of opening the capital account in the presence of trade distortions will not arise [Edwards and van Wijnbergen 1983].

\section{Summary and Concluding Remarks}

In this paper I have surveyed some of the most important issues related to the order of liberalization of the current and capital accounts of the balance of payments. This topic has recently attracted considerable attention both from academic and policy-oriented circles. From a theoretical point of view the question of the appropriate order of liberalization is only relevant in a world with some kind of adjustment costs, market imperfections and/or externalities. If, on the contrary, a textbook economy free of imperfections is assumed, the answer to this question becomes trivial: both accounts of the balance of payments should be liberalized simultaneously and instantaneously. However, there are a number of reasons, both economic and political, why a simultaneous and instantaneous liberalization might not be feasible. In this context, then, the question regarding the order of liberalization becomes important. 
The problem of the order of liberalization of the current and capital accounts of the balance of payments has become more interesting in light of the recent experience of a group of countries from the Cone of South America (Argentina, Chile and Uruguay). These countries followed opposite orders -Argentina and Uruguay opened the capital account first, while Chile opened the current account first-- with a common fate in the early 1980s: deep economic recession and (partial) reversal of the liberalization attempt. This Southern-Cone experience has triggered greater concern on the issue of the adequate order of liberalization. At the present time there are no definite answers regarding these experiences and more research on the subject should be en couraged.

The present paper has focused exclusively on the analysis of some aspects of the order of Iiberalization of the capital and current accounts of the balance of payments. However, there are a number of important issues related to a broadly defined liberalization process that deserve to be briefly mentioned. There are four major issues related to these reforms: First, if a liberalization will not fully eliminate all distortions, the question of welfare effects of partial reforms will become critical. Even though from a second-best perspective almost anything, in terms of welfare, can happen as a consequence of a partial reform, there are well founded conjectures that the liberalization of some markets only will be welfare Improving. 83 ' Second, the question of the speed of liberalization is also important. In the absence of market imperfections and/or externalities, markets should be liberalized very quickly (now). If externalities are present, however, and the first best

83' Krueger (1983b), Michaely (1992), Jorbo de Melo (1982). 
policies to deal with them are not avallable, a gradual liberalization might be called for. $84 /$ Third, the relationship between liberalization and stabilization is crucial to understand the success or fallure of liberalization reforms, since most liberalization attempts have been undertaken in conjunction with major stabilization programs. $85 /$ The reason for this is that, in the first place, the initial imposition of restrictions and controls is usually related to an increase in the fiscal deficit and inflation. There are some important aspects of the relationship between these two policies -stabilization and liberalization -- that deserve further attention. In particular, the desirability of implementing a major (almost full) liberalization at the same time as a stabilization program is on its way, should be further investigated. And, fourth, the order of liberalization (1.e., which market should be liberalized first) is also important. There is generalized agreement among experts about some aspects of the order of liberalization. There is agreement, for example, that the capital account should only be opened after the domestic capital market is freed, and that this can only happen after the fiscal deflcit has been substantially reduced. There has been less agreement, however, on the order of liberalization of the capital and current accounts. This is the topic that has been discussed in the present paper.

In Section 2 of the present paper the existing literature on the order of liberalization of the capital and current accounts of the balance of

84/ See Leamer (1981), Mussa (1982), Neary (1982), Edwards (1982), Michaely (1982) and Edwards and van Wijnbergen (1983).

85/ See Krueger $(1978,1981,1983 a)$, Little (1982). 
payments was critically reviewed, and some interpretations were suggested. The existing arguments were grouped in three broad categories for this discussion. The first line of argument is concerned with real exchange rate behavior and macroeconomic stability during the liberalization effort. Some authors have argued that to the extent that the opening of the capital account will generate destabilizing capital flows, the real exchange rate will be highly volatile after this account is 11 beralized. For this reason, the reasoning goes, the capital account should only be opened after the trade reform has been completed, and the new structure of production is "consolidated". Other authors, however, have argued that the best way to avoid undesired real exchange rate movements is by having a freely floating exchange rate with full convertibility. This exchange rate system, they argue, should be implemented before the trade reform. Consequently, according to this view the capital account should be liberalized first. The second line of argument that appears in the 1 iterature is related to welfare effects of particular orderings. This analysis centers on plausible values of cross elasticities and of indirect welfare effects. The third group of arguments deals with the problem of adjustment costs and the provision of adjustment assistance through cheaper foreign credit. While some authors believe that the higher availability of cheaper foreign credit -- obtained through the opening of the capital account -- will help the adjustment process, others think that the effect of this credit will be highly undesirable since the "wrong" signals will be provided, and that capital flows should be avoided during the transition following a trade reform. 
In Section 3 a positive analysis of the effects of Ilberalizing both accounts was presented. A three goods-two factors model of trade was used to analyze how both reforms will affect production and income distribution in the short- and long-run. The model assumes that the short-run can be characterized by a Ricardo-Viner setting, while in the long-run a Hecksher-Ohlin framework is used. This discussion shows that both reforms, on their own, will tend to generate opposite effects on production and income distribution. To the extent that there are real costs related to resource movements, there is an argument to synchronize the effects of opening both accounts, in order to avoid resources moving in and out of particular sectors. If, as has been suggested by Frenkel [1982, 1983] and Khan and Zahler [1983] among others, the speed of adjustment of the capital account is faster than that of the current account, this synchronization of the economic effects of opening both accounts will require that the current account is opened first.

In Section 4 a two-period model of a small open economy was developed to analyze the welfare consequences of liberalizing the capital account in the presence of trade distortions. It was shown that these welfare effects will depend on two key variables. First the relationship, prior to the liberalization reform, between the domestic consumption rate of interest and "the" world interest rate will be critical. If the domestic consumption interest rate exceeds the world rate of interest the opening of the capital account will result in an importation of capital and welfare will improve. Second, the social welfare consequences of opening the capital account in the presence of tariffs will depend on whether the additional funds obtained from abroad are used for capital accumulation or for consumption. It was shown that if $f$ unds 
are used to increase present consumption welfare will always improve. Moreover it is shown that under these assumptions the welfare increase will be greater in the presence of tariffs. If, however, these funds are used to increase investment in the presence of tariffs welfare may be reduced as a consequence of the capital account liberalization. This welfare reduction will not take place, however, if shadow prices are used to gulde investment decisions.

The purpose of this paper has been to survey the major issues related to the order of libralization, presenting the different aspects of this problem in an organized fashion. While the analysis has not yielded a strong theorem regarding the appropriate order for liberalizing the current and capital accounts of the balance of payments, both the historical evidence and the theoretical considerations discussed suggest that a more prudent strategy would be based on liberalizing the current account first.

A central aspect of any reform package is related to the degree of credibility that the public has on the reform. If there is no credibility, agents will not make the decisions required for the new policy to have an effect on the economic structure: Moreover, in the particular case of the liberalization of the current and capital accounts of the balance of payments, the lack of credibility can result -- as was the case of Argentina -- in agents using foreign funds to increase investments in the "wrong" sector. $86 /$ of course, the degree of credibility of a reform package is not

86/ Of course, if the lack of credibility was founded, and the reforms are reversed, the investment was being done (from a private perspective) in the "right" sectors. 
an exogenous variable, but will depend on a number of variables. One of the most important determinants of the degree of credibility is the perceived consistency of the proposed policies. If these policies are percelved as inconsistent, then agents will expect that the reform attempt will be discontinued or reverted. This is a basic, but important principle that should be kept in mind when implementing global economic reforms. In that sense, it may be argued that more important than determining the correct order of Iiberalization, it is important to define consistent and credible policy packages that will support any particular order that is chosen. 


\section{References}

Arriazu, Ricardo: "Policy Interdependence From a Latin-American Perspective," IMF Staff Papers, 30, 1 (March 1983): 113-152.

: "Remarks on the Southern Cone," IMF Staff Papers, 30, 1

(March 1983): 177-184.

Aizenman, Joshua: "Dynamics of Trade Liberalization Policy," Journal of Development Economics (1983).

Balassa, Bela: "Principios de Reformas Arancelarias en Paises en Desarrollo," in Estudios Monetarios IV (Banco Central de Chile, 1976): 11-26.

: Development Strategies in Semi-Industrial Economics, (Oxford University Press 1978).

: "Reforming the System of Incentives in Developing Economies," in B. Balassa (ed.) Development Strategies in Semi-Industrial Economies (Oxford University Press 1982).

Bertrand, T.S. and F. Flatters: "Tariffs, Capital Accumulation and Immisirizing Growth," Journal of International Economics (1971): 453-460.

Bhagwati, J.: The Theory and Practice of Commercial Pollcy: Departures From Unified Exchange Rates (Princeton University Special Papers No. 8, 1968).

: Anatomy and Consequences of Exchange Control Regimes

(Ballinger:

New York 1978).

: "Directly Unproductive Profit Seeking Activities," Journal of Political Economy (October 1982). 1982).

: Import Competition and Response (University of Chicago Press,

and T,N. Srinivasan: "Trade Policy and Development," in R. Dornbusch and J.A. Frenkel (eds.) International Economic Policy: Theory and Evidence, (Johns Hopkins University Press 1979).

and : "Revenue Seeking: A Generalization of the Theory of Tariffs," Journal of Political Economy (December 1980).

and $\quad$ Lectures in International Trade (MIT Press $1983 a$ ).

and : "On the Choice Between Capital and Labor Mobility," Journal of International Economics (May 1983): 209-222. 
Blejer, M. and L. Landau: Economic Liberalization and Stabilization in Argentina, Chile and Uruguay: The Monetary Approach to the Bal ance of Payments (The World Bank, forthcoming 1984).

and Donald J. Mathieson: "Preannouncement of Exchange Rate Changes as a Stabilization Instrument," IMF Staff Papers (December 1981).

Branson, William: "Remarks on the Southern Core," IMF Staff Papers (March 1983):

Brecher, R.A.: "Minimum Wage Rates and the Theory of International Trade," Quarterly Journal of Economics (1974): 98-116.

: "Optimal Commercial Policy for a Minimum Wage Economy," Journal of International Economics 4 (1974): 139-149.

Brecher, R. and J. Bhagwati: "Immiserizing Transfers From Abroad, "Journal of International Economics (1982): 353-364.

and C. Diaz-Alejandro: "Tariffs, Foreign Capital and Immiserizing Growth," Journal of International Economics (1977):

and R. Findlay: "Tariffs, Foreign Capital and National Welfare with Sector Specific Factors," Journal of International Economics (May 1983): 277-288.

Bruno, Michael: "Import Competition and Macroeconomic Adjustment Under WagePrice Rigidity," in J. Bhagwati (ed.) Import Competition and Response (University of Chicago Press 1982).

Calvo, Guillermo: "Trying to Stabilize: Some Theoretical Reflections Based on the Case of Argentina," Columbia University Workding Paper No. 128 (1981).

: "Devaluation: "Levels vs. Rates," Journal of International Economics (May 1981).

: "The Chilean Economy in the 1970's," in K. Brunner and A. Meltzer (eds.) Economic Policy in a World of Change, v. 17 CarnegieRochester Conference Series 1982.

Cavallo, D. and Y. Mundlak: Agriculture and Economic Growth in an Open Economy: The Case of Argentina: (IFPRI, 1982).

Clark, Paul: "Step-by-Step Liberalization of a Controlled Economy: Experience in Egypt," unpubl ished paper, 1982.

Corbo, Vittorio: "Recent developments of the Chilean Economy," unpublished paper, prepared for the conference on "National Economic Policies in Chile" (November 1982). 
and Sebastian Edwards: "El Rol de Una Devaluacion en la Economi a Chilena Actual," unpublished paper (June 1981)

and Jaime de Melo: "Liberalization with Stabilization in the Southern Cone," unpublished paper 1982.

Corden, W.M.: "The Exchange Rate, Monetary Policy and North Sea 011," Oxford Economic Papers (1981): 23-46.

: "Exchange Rate Protection," in R.N. Cooper et al. (eds.) The International Monetary System Under Flexible Exchange Rates (Ballinger 19181).

: "Booming Sector and Dutch-Disease Economics: A Survey," Australian National Uni versity Working Paper No. 079, 1982.

and J.P. Neary," Booming Sector and De-industrialization in a Small Open Economy," Economic Journal (1982): 825-48.

Datta, G.: "Capital Importing Oil Exporters: Macroeconomic Issues in a Period of Rapidly Improving Terms of Trade," unpublished paper, The World Bank, 1983.

Diaz-Alejandro, Carlos F.: "Southern Cone Stabilization Plans," in William R. Cline and Sidney Weintraub (eds.) Economic Stabilization in Developing Countries (Washington, D.C.: Brookings Institution, 1981). : "Good-Bye Financial Repression, Hello Financial Crash," unpublished paper 1983.

Dixit, Avinash and Victor Norman: Theory of International Trade (Cambridge University Press 1980).

Dornbusch, Rudiger: "Tariffs and Non-traded Goods," Journal of International Economics (May 1974): 117-185.

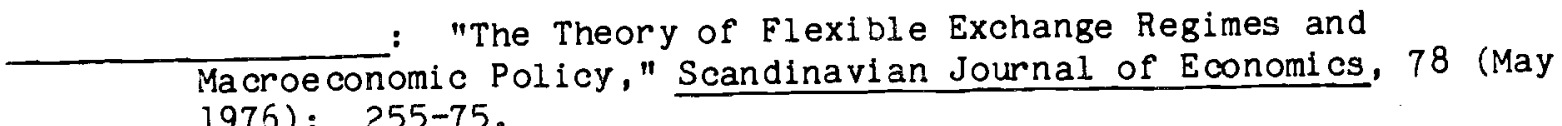
1976): 255-75.

: Open Economy Macroeconomics, Basic Books, New York 1980.

: "Remarks on the Southern Cone," IMF Staff Papers (March 1983).

: "Real Interest Rates, Home Goods and Optimal External Borrowing," Journal of Political Economy (February 1983): 141-153. 
Edwards, Sebastian: "Minimum Wages and Trade Liberalization: Some Reflections Based on the Chilean Experience," Working Paper No. 230, Dept. of Economi cs, UCLA, 1982a.

: "The Short-Run Relation Between Grown and Inflation in Latin-America: Comment," American Economic Review (June 1983): 47782.

: "LDC's Foreign Borrowing and Default Risk: An Empirical Investigation 1976-1980," American Economic Review (September 1984).

: "Economic Policy and Growth in Chile: 1973-1982," in G. Walton (ed.) National Economic Policies in Chile forthcoming 1984.

: "Stabilization with Liberalization: An Evaluation of Ten Years of Chile's Experiment with Free Market Policies, 1973-1983", Economic Development and Cultural Change (January 1985a).

: The Order of Liberalization of the External Sector in Developing Countries, Princeton Essays in International Finance: Princeton, N.J. (Forthcoming 1985b). and Masanao Aoki: "Oil Export Boom and Dutch Disease," Resources and Energy (1983).

and Sweder Van Wijnbergen: "The Welfare Effects of Trade and Capital Market Liberalization: Consequences of Different Sequencing Scenarios," NBER Working Paper No. 1245, December 1983.

Feldstein, Andrew: "A General Equilibrium Approach to the Analysis of Trade Restrictions with an Application to Argentina," IMF Staff Papers 27 (1980): 749-774.

Fellner, William: "In Defense of the Credibility Hypothesis," American Economic Review (May 1982): 90-92.

Fischer, Stanley and Jacob Frenkel: "Investment, the Two-Sector Model, and Trade in Debt and Capital Goods," Journal of International Economics (August 1972): 211-233.

and : "International Capital Movements Along Balanced Growth Paths: Comments and Extensions," Economic Record, 48 (June 1972): 266-271.

Fleming, J.M.: "Dual Exchange Markets and Other Remedies for Disruptive Capital Flows," IMF Staff Papers 21 (1974): 1-28.

Flood, Robert: "Exchange Rate Expectations in Dual Exchange Markets," Journal of International Economics (1978): 65-77. 
Frenkel, Jacob: "The Order of Economic Liberalization: Discussion," in K. Brunner and A.H Meltzer (eds.) Economic Policy in a World of Change (North-Holland, 1982). 1983)

: "Remarks on the Southern Cone," IMF Staff Papers (March

Fry, Maxwell: "Money and Capital or Financial Deepening in Economic Development," Journal of Money, Credit, and Banking (1978): 464-475.

: "Savings, Investment, Growth and the Cost of Financial Repression," World De velopment, 8 (April 1980): 317-327.

Fullerton, Don: "Transition Losses of Partially Mobile Industry-Specific Capital," Quarterly Journal of Economics (February 1983): 107-126.

Galbis, Vicente: "Financial Intermediation and Economic Growth in LessDeveloped Countries: A Theoretical Approach," Journal of Development Studies (1977): 58-72.

Grossman, Gene: "The Gains from International Factor Movements," unpubl ished manuscript, May 1983.

Hanson, James: "Optimal International Borrowing and Lending," American Economic Review, 64 (September 1974): 616-630.

and Jaime de Melo: "The Uruguayan Experience with

Liberalization and Stabilization," Journal of Inter-American and World Affairs, 1983.

Harberger, Arnold C.: "Using the Resources at Hand More Efficiently," American Economic Review (May 1959).

: "Notas Sobre la Dinamica de la Liberalizacion del

- Comercio," in Estudios Monetarios III (Banco Central de Chile, 1976).

: "On Country Risk and the Social cost of Forelgn

Borrowing by Developing Countries," unpublished manuscript, University of Chicago 1976.

: "A Primer on Inflation," Journal of Money, Credit and Banking (August 1978): 505-21.

: "Vignettes on the World Capital Market," American Economic Review Papers and Proceedings, 70 (May 1980): $331-337$.

: "The Chilean Economy in the 1970s: Crisis, Stabilization, Liberalization, Reform," in K. Brunner and A.H. Meltzer (eds.) Economic Polloy in a World of Change (North-Holland, 1982). 
and Sebastian Edwards: "International Sources of

Inflation: Some New Results;" unpublished manusoript, 1982.

Johnson, Harry G.: "The Galns From Freer Trade With Europe: An Estimate," (Manchester School of Economlcs and Social Studies, Sept. 1958).

: "Optimal Trade Intervention in the Presence of Domestic Dostortions," in R. Caves et al. (eds.) Trade Growth and Balance of Payments (Rand-McNally, 1965).

: The Possibility of Income Losses From Increased Efficiency or Factor Accumulation in the Presence of Tariffs," Economic Journal (March 1967): 151-154.

Jones, R.J.: "A Three Factor Model in Theory, Trade and History," in J. Bhagwati (ed.) Trade, Balance of Payments Growth (North-Holland, 1971).

Kapur, Basant: "Optimal Financial and Forelgn Exchange Liberallzation of Less-Developed Economies," Quarterly Journal of Economics (February 1983): $41-62$.

Khan, Mohs in and Roberto Zahler: "The Macroeconomic Effects of Changes in Barriers to Trade and Capital Flows: A Simulation Analysis," IMF Staff Papers (June 1983): 223-282.

Krueger, Anne 0.: "The Political Economy of the Rent Seeking Society," American Economic Review (June 1974):

: Foreign Trade Regimes and Economic Development: Liberalization Attempts and Consequences (Cambridge, MA, 1978). : Trade Policy as an Input to Development," American Economic Review (May 1980).

: "Interactions Between Inflation and Trade objectives in Stabilization Programs," in W.R. Cline and S. Weintraub (eds.) Economic Stabilization in Developing Countries (Washington, D.C.: Brookings Institution, 1981).

: Trade and Employment in Developing Countries (University of Chicago Press, 1983a).

: "The Problems of Liberalization," unpublished paper, The World Bank, 1983.

Krumm, Kathie: "Credibility and Investment: Argentina's Attempted Liberalization 1976-1981," unpublished paper 1983.

Lal, Deepak: "The Real Aspects of Stabilization and Structural Adjustment Policies - An Approach," unpublished manuscript, World Bank 1982. 
Lanyi, Anthony: "Separate Exchange Rate Markets for Current and Capital Transactions," IMF Staff Papers (1975): 714-739.

Leamer, E.E.: "Welfare Computations and the Optimal Staging of Tariff Reductions in Models W1th Adjustment Costs," Journal of International Economi cs (February 1980).

Little, Ian M.D.: Economic Development (Basic Books, 1982).

, T. Scitovsky and M. Scott: Industry and Trade in Some Developing Countries (Oxford University Press, 1970).

and Marcelo Selowsky: "Energy Prices, Substitution and Optimal Borrowing in the Short-run: An Analysis of Adjustment in oil-Importing Developing Countries," Journal of Development Economics (forthcoming 1984).

Mayer, W.: "Short Run and Long Run Equilibrium for a Small Open Economy," Journal of Political Economy (1974).

McKinnon, Ronald J.: Money and Capital in Economic Development (Brookings Institution, 1973).

: "Foreign Exchange Rate Policy and Economic

Liberalization in LDC's," unpublished paper 1979.

: "International Transfers and Non-Traded Commodities: The Adjustment Problem," in D.M. Leipziger (ed.) The International Monetary System and the Developing Nations (AID, 1976).

: Money In International Exchange: The Convertible Currency System (Oxford University Press, 1979).

: "Financial Repression and Liberalization Problems in LDC's," in S. Grossman and E. Lundberg (eds.) The Past and Prospects of World Economic Order (MacMillan, 1980).

: "The Order of Economic Liberalization: Lessons from Chile and Argentina," in K. Brunner and A. Meltzer, (eds.), Economic Policy in a World of Change (North-Holland, 1982).

and D.J. Mathiason: How to Manage a Repressed Economy

(Essays in International Finance, Princeton University Press, 1981).

Meade, J.E.: The Balance of Payments, (Oxford University Press, 1951).

Melvin, James: "Production and Trade ith Two Factors and Three Goods," American Economic Review (1968): 1249-1268. 
Michaely, Michael: "The Sequencing of a Liberalization Policy: A Preliminary Statement of Issues," unpublished paper, 1982.

Munoz, Oscar: "Crecimiento y Desequilibrios en Chile," Estudios Cieplan, 8 (1982).

Mussa, M.L." "Tariffs and the Distribution of Income: The Importance of Factor Specificity," Journal of Political Economy (1974).

: "Dynamic Adjustment in the Heckscher-Ohl in-Samuelson Model," Journal of Political Econony (1978): 1191-1203.

: "The Two Sectors Model in Terms of its Dual: A Geometric Exposition," Journal of International Economics (November 1979): 513-526.

: "Government Policy and the Adjustment Process," in J. Bhagwati (ed.) Import Competition and Response (University of Chicago Press, 1982): 73-120.

Neary, Peter: "Short-Run Capital Specificity and the Pure Theory of International Trade," Economic Journal, 88 (1978): 448-510.

: "Dynamic Stability and the theory of Factor-Market Distortions," American Economic Review (1978): 671-682.

: "Capital Mobility, Wage Stickiness and the Case for Adjustment Assistance," in J. Bhagwati (ed.) Import Competition and Response (University of Chicago Press, 1982).

Nogues, Julio: "Politica Comercial y Cambiaria: Una Interpretacion de la Experiencia Argentina 1976-1981," Banco Central de Argentina, 1983.

Pindyck, Robert S.: "The Optimal Phasing of Phased Deregulation," Journal of Economic Dynamics and Control, 4. (1982), 281-294.

Rodriguez, Carlos A.: "Politicas de Estabilizacion en la Economia Argentina 1978-1982," Cuadernos de Economia (April 1983)

Rybczynsk1, T.M.: "Factor Endowments, International Trade, and Factor Prices;" Economica (November 1955): 336-341.

Schelling, Thomas: "Establishing Credibility: Strategic Considerations," American Economic Review (May 1982): 77-80.

Sjaastad, Larry: "Failure of Economic Liberalism in the Cone of Latin America," The World Economy (March 1983): 5-26.

and Hernan Cortes: "La Politica Economica de la Reforma Comercial en Chile," Cuadernos de Economia (Octubre/Diciembre 1981). 
Squire, Lyn: Employment Policies for Developing Countries, (Oxford University Press, 1983).

Srinivasan, T.N.: "International Factors Movements," Journal of International Economics (May 1983).

Stockman, Alan C.: "The Order of Economic Liberalization: Comment," in K. Brunner and A.H. Meltzer Economic Policy in a World of Change (NorthHolland, 1982).

Svensson, Lars 0 , and Arsaf Ragin: "The Terms of Trade and the Current Account," Journal of Political Economy (February 1983): 97-125.

Taylor, John: "Establishing Credibility: A Rational Expectations View," American Economic Review (May 1982): 81-86.

Van Wijnbergen, Sweder: "The Dutch Disease: A Disease After All?" mimeo 1983; forthcoming in Economic Journal 1984. 